\title{
Review Article \\ Polymeric Nanogels as Versatile Nanoplatforms for Biomedical Applications
}

\author{
Fakhara Sabir, ${ }^{1}$ Muhammad Imran Asad, ${ }^{1}$ Maimoona Qindeel, ${ }^{1}$ Iqra Afzal, ${ }^{1}$ \\ Muhammad Junaid Dar, ${ }^{1}$ Kifayat Ullah Shah $\mathbb{D}^{1},{ }^{1}$ Alam Zeb $\mathbb{D}^{2},{ }^{2}$ Gul Majid Khan, \\ Naveed Ahmed (D), ${ }^{1}$ and Fakhar-ud Din (D) $^{1}$ \\ ${ }^{1}$ Department of Pharmacy, Quaid-i-Azam University, Islamabad, Pakistan \\ ${ }^{2}$ Riphah Institute of Pharmaceutical Sciences, Riphah International University, Islamabad, Pakistan
}

Correspondence should be addressed to Naveed Ahmed; natanoli@qau.edu.pk and Fakhar-ud Din; fudin@qau.edu.pk

Fakhara Sabir and Muhammad Imran Asad contributed equally to this work.

Received 27 November 2018; Revised 15 March 2019; Accepted 27 March 2019; Published 16 May 2019

Academic Editor: Ruibing Wang

Copyright (c) 2019 Fakhara Sabir et al. This is an open access article distributed under the Creative Commons Attribution License, which permits unrestricted use, distribution, and reproduction in any medium, provided the original work is properly cited.

\begin{abstract}
Nanomaterials have found extensive biomedical applications in the past few years because of their small size, low molecular weight, larger surface area, enhanced biological, and chemical reactivity. Among these nanomaterials, nanogels (NGs) are promising drug delivery systems and are composed of cross-linked polymeric nanoparticles ranging from 100 to $200 \mathrm{~nm}$. NGs represent an innovative zone of research with speedy developments taking place on a daily basis. An incredible amount of focus is placed on the fabrication of NGs with novel polymers to achieve better control over the drug release. This review article covers a number of aspects of NGs including their types, associated pros and cons, and methods of preparation along with technical and economical superiority and therapeutic efficacy over each other. The last part of review summarizes the applications of NGs in the drug delivery and treatment of various diseases including brain disease, cardiovascular diseases, oxidative stress, diabetes, cancer therapy, tissue engineering, gene therapy, inflammatory disorders, pain management, ophthalmic and autoimmune diseases, and their future challenges. NGs appear to be an outstanding nominee for drug delivery systems, and further study is required to explore their interactions at the cellular and molecular levels.
\end{abstract}

\section{Introduction}

Appropriate drug delivery systems can be characterized by several factors including pharmacodynamic, pharmacokinetic, and physiochemical properties of the drug. Different carrier systems including hydrogels, nanogels (NGs), dendrimers, drug conjugates, and micelles have been used for several years for the effective delivery of drugs [1]. One of the most prominent and convenient systems among them is the hydrogel which could be attributed to its physiochemical and biological characteristics to achieve a site-specific delivery of incorporated drugs [2]. Previously, hydrogels with macro sizes were extensively used for various medical applications. However, with the advancement in nanotechnology, NGs were developed which are considered more suitable for optimum delivery at the target site due to their small size, ease of formulation, improved retention time, and swelling properties [3-6]. NGs are hydrogels with a submicron size range of 100-200 nm [7] or particles less than $200 \mathrm{~nm}$ composed of a cross-linked network of polymers via different functional groups such as carboxyl $(\mathrm{COOH})$, hydroxyl $(\mathrm{OH})$, amino $\left(\mathrm{NH}_{2}\right)$, and sulphonic $\left(\mathrm{HSO}_{3}\right)$ [8-10]. NGs are composed of physiochemical-bound natural and synthetic polymers [11], active ingredients, and solvents [12, 13]. NGs may consist of a charged or non-charged system of amphiphilic molecules. The drug loading of NGs requires a basic physiochemical interaction between functional groups of polymeric compounds and drug substance $[14,15]$.

A nanosize regimen is designed to overcome some of the limitations of micron size particles, including surface area, 


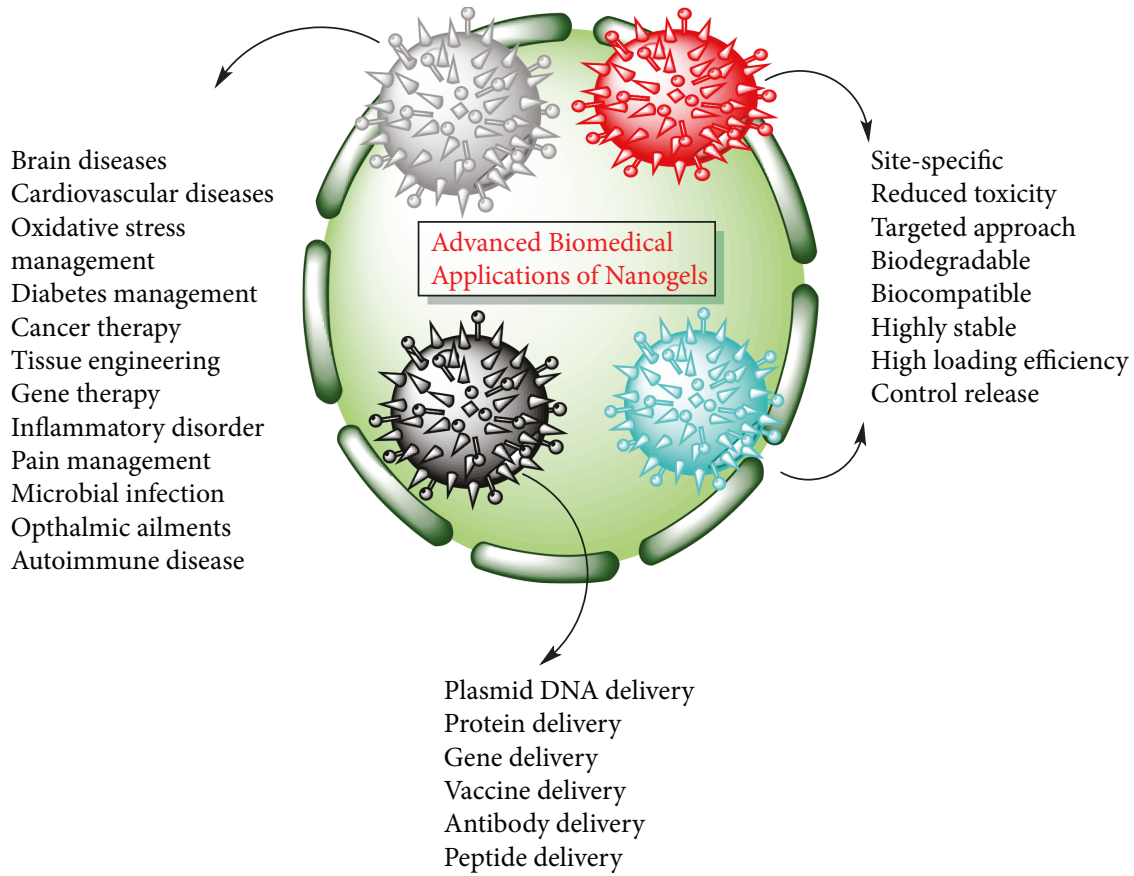

FIGURe 1: Advanced biomedical applications of NGs.

site specificity, retention at targeting site, swelling behavior, drug loading, and release behavior. Ideally, NGs are considered as biocompatible, biodegradable, versatile, and safe from any kind of leakage [4, 16-18]. Size control is easy in NGs to induce active or passive delivery [19]. NGs are utilized in many medical situations including cancer and inflammatory conditions owing to their stimulus-responsive behavior. Under various diseased conditions (for example, cancer and inflammation), body functionality changes due to altering metabolic and/or physiological states. The conventional delivery systems are unable to respond to these minor physiological variations such as $\mathrm{pH}$ and temperature, thereby making it very challenging to display a proper drug release profile and therapeutic effects $[17,20,21]$. In such cases, NGs are very useful because their stimulus responsiveness increases several times leading to the required drug delivery at the targeted site for a desired therapeutic effect [22]. One of the many reasons for selecting NGs as a drug delivery system is their toxicity reduction through transdermal delivery of active pharmaceutical ingredients (API), an example of which includes aceclofenac-loaded NG [23]. This could also be attributed to the fact that NG mostly consists of polymers which are biodegradable and degraded into nontoxic metabolites. Furthermore, NG formulation for psoriatic skin is a new area where recently a number of trials are performed. For cancer treatment, a variety of polymeric NGs loaded with doxorubicin are reported earlier [24, 25].

In this review, we discuss different aspects of NGs, their classification, their methods of preparation, and their advanced biomedical applications in various ailments including brain disorders, cardiac diseases, pain management, diabetes, tissue engineering, cancer treatment, gene therapy, and inflammatory disorders (Figure 1). This review also highlights the advancement of nanotechnology in the field of NGs supported by the latest references from the literature.

\section{Types of NGs}

NGs can be classified into different types on the basis of their structural properties including artificial chaperones, layerby-layer NGs, functionalized NGs, core-shell NGs, and hollow NGs [26]. A comprehensive description of all the types is given below.

2.1. Artificial Chaperones. These are cross-linked, selfassembled particles with extensive applications in various fields of biomedicine [26]. They are used as a drug transporter and synthetic molecular chaperones. The representative diagram of artificial chaperones is given in Figure 2. Artificial chaperones are made up of cross-linked, bifunctional systems of polyion and anionic polymers for the transport of polynucleotides (cross-linked PEI-PEG or PEG-CLPEI). One of the examples of artificial chaperones is the development of cholesterol-bearing pullulan (CHP) [27, 28] - They have multihydrophobic zones which can entrap hydrophobic drugs and proteins inside them. CHP has been majorly employed as a drug carrier, in particular for hydrophobic drugs [29-31]. Similarly, another class of artificial chaperones (polysaccharide-based hybrid NGs) was reported to offer extensive opportunities for diagnosis and therapy [32]. These NGs not only exhibited exceptional stability as a drug carrier for a model anticancer drug temozolomide but also offered a $\mathrm{pH}$-triggered sustained release of drug molecules from the gel network [33]. Furthermore, in comparison to the liposome-loaded quantum dots (QDs), NG-bearing QDs have improved the capacity for imaging utilizing a lesser quantity [33, 34].

2.2. Layer-by-Layer NGs. These are cross-linked, stimulusresponsive NGs and are also known as multilayer NGs 


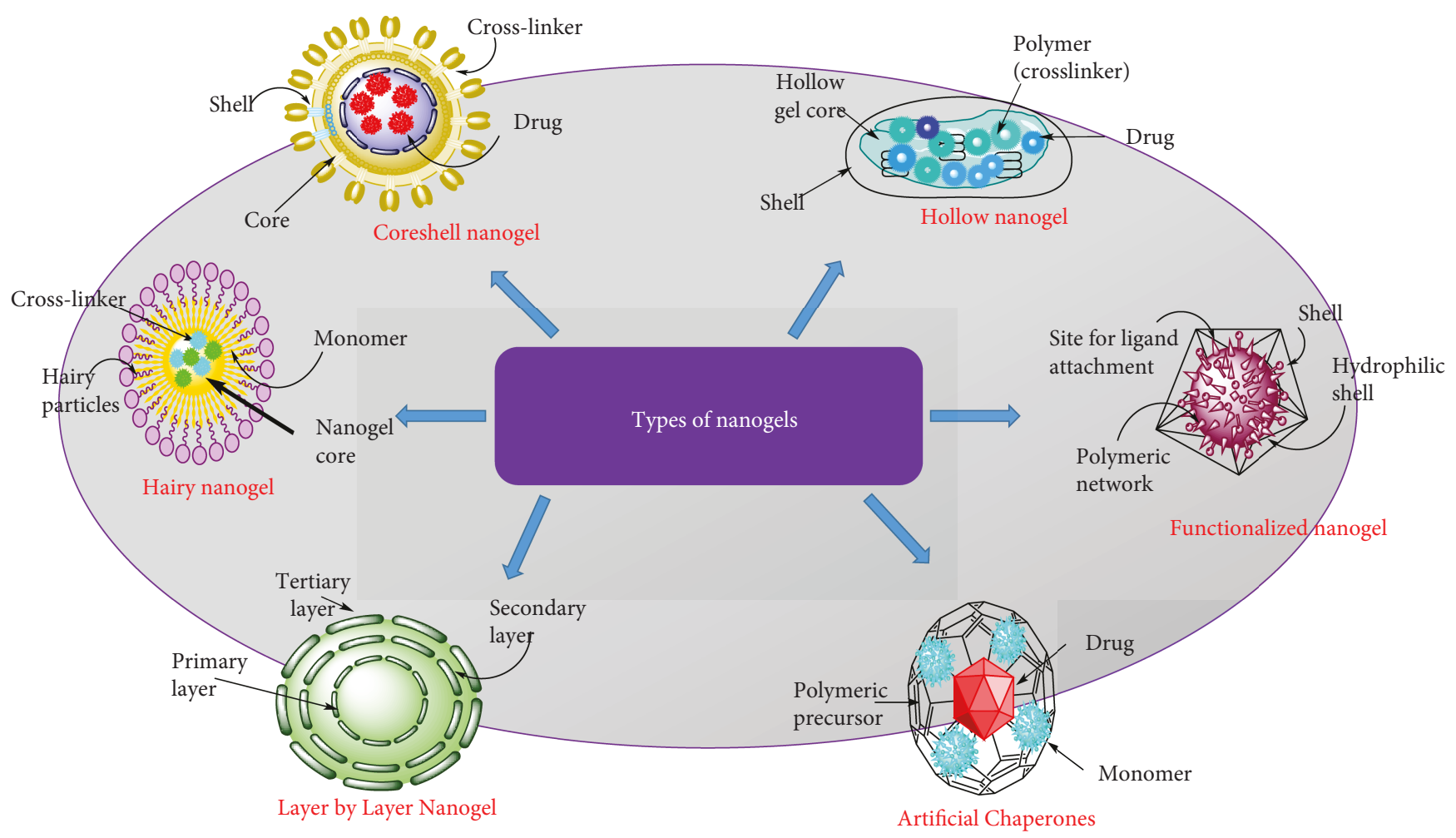

Figure 2: Types of NG formulations.

(Figure 2). These multilayers are formulated in different dimensions to expose their efficiency as a best carrier for stimulus responsiveness. Different templates are used such as rigid particles, microgels, and NGs. NG is the most successful approach, and unlike the others, it does not lead to deformability and deposition at the site of action or inside the body [35]. Initially, a single particle light scattering technique was used for formulating multilayer NGs. However, this technique is not suitable for thermosensitive microgels because of their soft, porous, and solvent-penetrable polymeric networks, characterized by the alleged volume phase transition from an engorged to a collapsed state during heating. Various scanning techniques are used for evaluating the thickness of layer-by-layer assembly such as confocal laser electron microscopy, dynamic light scattering (DLS), and fluorescence correlation spectroscopy [36-38].

2.3. Functionalized NGs. These types of NGs are a crosslinked water-soluble polymeric nanoparticle network that is formulated to overcome the stability issues associated with layer-by-layer NGs (Figure 2). These are extensively used NGs; however, their formulation methods are very complicated and require high purification at every step [35], including the microemulsion or inverse microemulsion technique. For instance, water-soluble polymeric nanoparticles are incorporated in NGs using the inverse microemulsion method. In this regard, surface modification of layer-bylayer NGs is performed through cross-linking, covalent coupling, and physical, thermal, or chemical posttreatments [39]. This method of formation of functionalized NGs has advantages over other methods including its single-step process without the use of external cross-linkers, fast crosslinking reactions, no undesirable side products, and covalent grafting of active molecules (functional groups) to the surface. To formulate a stimulus-sensitive functional group, disulfide bonds are selected as these bonds are more sensitive to bioreductive agents such as glutathione (GSH) and thioredoxin. Additionally, thiol-containing functional groups, if added on polymers, result in higher reactivity which could be attributed to the functionalized property of pyridyl disulfide (PDS) bond of the thiol group as compared to several other disulfide functionalities. Therefore, nanoparticlebased NGs can easily be functionalized leading to their therapeutic application in control release formulations $[4,40]$.

2.4. Core-Shell NGs. These are cross-linked stimulus-sensitive NGs made up of polymers with different sensitivities and consisting of core and shell compartments. Core-shell NGs consist of two regions which are chemically coupled with one another (Figure 2). This coupling or cross-linking also affects their stimulus-responsive property and makes them different from other branched polymers. Backfolding of cross-link chains is not possible in core-shell NGs. There are many stimuli to which core-shell NGs are sensitive including temperature, pressure, and $\mathrm{pH}[41,42]$. The formulation of core-shell NGs is a very critical process depending upon several parameters such as size, core-shell density, and inclusion of functional groups in core-shell compartments. Various methods are used for the preparation of core-shell NGs such as precipitation polymerization, batch polymerization, and seed polymerization. NGs coated with different nanoparticles such as gold nanoshells and gold 
nanorods are available in the market and are applied in different temperature-sensitive therapies [43, 44]. Amphoteric core-shell NGs provide important information relevant to specific properties of core-shell NG. An evaluation of the internal structure of NGs can be done through theoretical modeling [45].

2.5. Hairy NGs. Hairy NGs consists of a dual structure having a core and a shell. The shell is composed of linear polymeric chains with high dispersibility (Figure 2). The core of hairy NGs consists of inorganic or polymeric material [46]. These nanomaterials respond to various stimuli including temperature, $\mathrm{pH}$, light, and enzymes. Among all the other types of NGs, thermosensitive hairy NGs are of great importance because of their very small size and stimulus responsiveness [47].

Different methods of preparation of hairy NGs are currently in use. One of them is grafting onto the process, but particles formed through this process have a high density. To address this issue, the controlled radical polymerization method is used, which provides various advantages on the formation of hairy NGs. Another method is the two-pot synthesis method which is generally and specifically used for hairy particles. The process runs over two parts: firstly synthesis, isolation, and purification of NG particles and secondly the synthesis of hairs or grafted straight chains over the particle surface [35]. The most recently developed method is the one-pot synthetic route in which NGs are synthesized by copolymerization of the monovinyl monomer and divinyl cross-linker. The advantage of one-pot synthesis is its convenience and the lack of the need of purification of the intermediates. The size of hairy NGs can be adjusted by changing the concentration of monomers. Thus, synthesis of hairy NG through the one-pot method is more advantageous among others $[47,48]$.

2.6. Hollow NGs. Hollow NGs are fabricated by temperaturesensitive polymers that are predominantly favorable constituents. The stimulus sensitivity, large size, composite covering, thickness and permeability, large storage capability, and release pattern describe their main features [39]. Therefore, the finding and regulation of all these features are of utmost significance for the preparation of hollow NGs. Hollow NGs with considerably cross-linked shells depict discrete temperature sensitivity but retain virtually no void (14\% of the initial core volume) and therefore hardly become hollow. NGs with a rigid shell (smaller void as compared to the core size of the template) are certainly hollow but have lowtemperature sensitivity [49].

One of the many advantages of hollow NGs is their improved drug loading, which could be attributed to their greater storage volume (Figure 2). Various methods used for their preparation include layer-by-layer assembly, selfassembly of lipids or block copolymers, template method, and ultrasonic fabrication [35]. However, loading capacities of these hollow nanoparticles may not significantly be enhanced as expected. To encounter this issue, hollow NGs can be synthesized with mesoporous channels penetrating from the shell to the hollow inner core. Hollow NGs prepared through this method have easy fabrication in the aqueous phase without any inclusion of the organic phase [50]. Hollow NGs can be formulated as a dual stimulus-responsive carrier from the continuous association of two graft copolymers into polymersomes [51].

\section{Synthesis of NGs}

Various synthesis techniques are used for the development of NGs, depending upon their intended pharmacologic effect, desired characteristics, and quantity of the final dosage form. A descriptive detail of all the techniques is given below.

\subsection{Polymerization of Monomers in a Homogeneous Phase or} in a Microscale or Nanoscale Heterogeneous Environment. Uniform nucleation of the water-soluble monomer results in the formation of colloidal suspension of the polymer. This in turn is used to prepare stable NGs. This method is of great importance in cases where particle size control is of prime importance because particle size has a prominent role in the stability of colloidal formulations. This particle size control is accomplished by the use of the ionic surfactant, and there is an inverse relationship between particle size and surfactant concentration [52]. This method was utilized by Donini and coworkers for lipophilic and temperatureresistant drugs [53]. Similarly, Luisi and Straub reported copolymerization of monomers in reverse micelles for the entrapment of hydrophilic drug molecules [54].

3.2. Physical Self-Assembly of Interactive Polymers. In this technique, hydrogen bonding and van der Waals forces result in an interaction between drug moiety and solvent [55]. During the self-assembling process of NGs, micro- and macromolecules are captured inside them. This method is used to prepare protein-loaded NGs by the self-association of water-soluble polymers. Akiyoshi et al. developed insulinloaded NGs using this technique. The particle size of NGs prepared with this technique had a particle size below $30 \mathrm{~nm}$; however, it was dependent upon polymer concentration and various environmental factors including $\mathrm{pH}$, temperature, and ionic strength. In a study, NGs with a particle size $(120-150 \mathrm{~nm})$ and enhanced stability were reported, using various ratios of two different polymers [30]. Furthermore, the reversible addition-fragmentation chain transfer (RAFT) technique [56] was used to make amphiphilic block copolymers which in turn were used to make NGs. The RAFT technique is a one-step production of PEGylated poly $\left(N, N^{\prime}\right.$-dimethylaminomethyl methacrylate) NG utilizing an amphiphilic trithiocarbonate which is a macro-RAFT agent along with hydrophobic (dodecyl) chain-assisting polymerization. Owing to the production of small particles, this technique is most suitable for the delivery of genes $[57,58]$. The micellar behavior of amphiphilic block copolymers can be improved by alternating the temperature conditions and adding solvents $[59,60]$. Similarly, a superficial behavior of NGs for site-specific targeting and their loading capacity can be enhanced. 
3.3. Cross-Linking of Preformed Polymers. In this technique, oil in water emulsion followed by removal of solvent is used to prepare large-sized NGs [61]. Branched PEG (thiol-functionalized) and dimethyl sulfoxide containing DNA are mixed to obtain cross-linked NGs having a DNA by utilizing the oxidation process [62]. NGs obtained via this method are rod-shaped, spherical, and toroid-shaped. This method is suitable to controlling certain parameters like size and shape of the particles, as well as composition and surface properties of the NGs.

3.4. Novel Photochemical Approach. In the photochemical method, NGs are manufactured in an interlayer quartz flask $(150 \mathrm{~mL})$ furnished with a stirrer and a nitrogen gas inlet. A precise quantity of nanoparticles (usually $10 \mathrm{mg}$ ) is mixed with $60 \mathrm{~mL}$ deionized water containing $186 \mathrm{mg}$ monomer. This mixture is stirred for $10 \mathrm{~min}$ followed by addition of $0.8 \mathrm{~mL}$ of $1 \mathrm{wt} \%$ cross-linker. Further, it is exposed to ultraviolet (UV) irradiation for $25 \mathrm{~min}$. $\mathrm{N}_{2}$ is effervesced throughout the preparation procedure. The NGs are collected, washed many times with distilled water, and redispersed in distilled water for further use [63]. This method was used to prepare amino-functionalized magnetic NGs of coated ferric oxide nanoparticles using $N$-(2-aminoethyl)methylacrylamide and $N, N^{\prime}$-methylene-bis-acrylamide for their application as an MRI contrast agent [64]. Likewise, DNA-loaded diacrylated Pluronic and glycidyl methyacrylated chito-oligosaccharide NGs were prepared by using UV light at a wavelength of $365 \mathrm{~nm}$ along with a photoinitiator [65]. These NGs were formulated to improve injectable deposition schemes for gene therapy which results in the enhanced indigenous transgene expression at injection sites.

Photochemical internalization along with siRNA NGs is also used for the prolonged gene silencing. Basically, various nonviral siRNA carriers get attached to the endosomal layers resulting in limited gene silencing. However, photosensitizer (meso-tetraphenylporphine disulfonate) is used during formulation which is responsible for the rupture of the endosomal membrane leading to the release of genes into the cytoplasm, thereby improving the intracellular bioavailability of siRNA [66].

3.5. Novel Pullulan Chemistry Modification. In this method, chemical modification of pullulan is done. Cholesterolbased pullulan (CHP) NGs are prepared by using a combination of cholesterol in DMSO and pyridine. Modification is done by replacing 1.4 moieties of cholesterol per 100 glucoside units. Freeze-drying is a prerequisite for the formulations prepared via this technique [67]. The CHP-based technique behaves as an efficient carrier for protein NG formulations. Modification of the CHP method is also done by Michael addition reaction in which PEG replaces the acrylate and thiol groups [68]. Changes at the 1.1 unit of cholesteryl per 100 glucose units make it favorable to interact with the $\mathrm{AB}$ monomer as well as monomers responsible for the treatment of diseases like Alzheimer [65]. When modification is made by using 1.6 units of glucose, pullulan suitable for targeting folate receptors is developed. NGs are formed when pullulan and the photosensitizer are conjugated with carbodiimide followed by dialysis. Such types of NGs are effectively used in cancer treatment [69]. For example, acetylated chondroitin sulfate augments the discharge of doxorubicin in HeLa cells for three weeks, which is very helpful in cancer therapy [70]. Similarly, the release profile and absorption of methotrexate are changed by saturation of butyl acrylate (BA) and $N$-isopropylacrylamide with sodium carbonate, changing the absorption and release profile of methotrexate [71]. Additionally, pH-modified hydroxypropyl methylcellulose- (HPMC-) polyacrylic acid is made by eliminating cadmium ions and polyacrylic acid and is exercised for bioimaging by detecting the physicochemical surrounding [72].

\section{Biomedical Applications of NGs}

4.1. Brain Diseases. Various nanoplatforms are recently utilized for the treatment of brain diseases including Alzheimer's disease (AD), depression, migraine, and schizophrenia. NGs are one of those nanodecorated drug delivery systems. Their efficacy in brain diseases is because of their improved therapeutic effects, better mechanism of targeting, and biological efficiency. AD is the irretrievable neurodegenerative illness leading to progressive loss of memory and intellectual abilities [73]. Although various pathological conditions are believed as the possible reasons of $\mathrm{AD}$, amyloid hypothesis is, however, widely accepted in this regard [74]. The anomalous buildup, accretion, and accumulation of amyloid $\beta$-protein $(\mathrm{A} \beta$ ) lead to the cerebral extracellular amyloid blockade that causes neurotoxicity $[75,76]$. Therefore, avoiding $\mathrm{A} \beta$ accumulation is believed as a favorable approach in the management of AD. For this purpose, NGs with a double inhibitor-modified hyaluronic acid function were fabricated with inhibiting capabilities of $A \beta$ accumulation, resulting in the management of $\mathrm{AD}$ [77]. Likewise, Elnaggar et al. assimilated piperine, a phytopharmaceutical agent in NGs for its neuroprotective effect in $\mathrm{AD}$ [78].

Similarly, NGs are reported to deliver olanzapine for the treatment of schizophrenia which is a brain disorder described by delusions and disordered behavior [79]. These NGs exhibited excellent entrapment and enhanced bioavailability. Moreover, $\mathrm{Hu}$ et al. prepared lidocaine hydrochloride-loaded NGs, for the management of migraine [80]. Lidocaine hydrochloride is a commonly used drug in the treatment of migraine; however, after incorporation in the NG, the drug showed better bioavailability with no toxicity. Furthermore, Dange et al. reported the development of venlafaxine-loaded NG for the treatment of depression [81]. This NG showed a quick onset of action with extended period of time as compared with the drug solution.

4.2. Cardiovascular Diseases. Cardiovascular diseases like myocardial infarction (MI) and heart failure are the main reason of human deaths globally [82]. Various strategies are adopted to treat these diseases including tissue engineering and stem cell transplantation $[83,84]$. Among the different drug delivery systems, injectable NGs have been used to treat MI. These NGs have confirmed the improvement in cardiac condition via LaPlace's Law, an act which is exhibited 
by increased wall thickness and reduced wall stress [85]. One such study reported the heart restoration using NGencapsulated human cardiac stem cells in mice and pigs with MI [86]. This study concluded that synthetic porous NGs act as a promising cell carrier for allogeneic/xenogeneic cell rehabilitations. Most particularly, these NGs inhibit the entry of immune cells while promoting the regenerative capabilities of the heart.

Another study demonstrated the development of thermoresponsive NGs to produce cell mass fragments for the treatment of ischemic diseases. Owing to their temperaturedependent behavior, the cell bodies are produced without proteolytic enzymes. The animal studies further exhibited the adherence of cell mass fragments with engraftment sites which in turn enhance the vascular density, hence treating the diseased condition of an infarcted heart [87].

4.3. Treatment of Oxidative Stress. Oxidative stress is a diseased condition in which the increased production of oxidants including hydroxyl radicals, singlet oxygen, and hydrogen peroxide lead to cellular disability. This increased level of oxidants may be produced by endogenous and exogenous sources which may result in development of many diseases including cardiovascular diseases, Parkinson's disease, and acute renal failure $[88,89]$. Various drug delivery systems are utilized to treat the oxidative stress; however, NGs are considered as reliable drug delivery vehicles in this regard [90-92]. For instance, quercetin-encapsulated poly(b-amino esters) NGs were developed for the treatment of cellular oxidative stress [93]. NGs with a size range at the nanoscale were developed with 25-38 drug wt $\%$ and constant drug release over a period of $45-48 \mathrm{~h}$. These NGs demonstrated an antioxidant activity of the drug for a prolonged time period. Another study exhibited the development of ferulic acidloaded NG with improved penetrability and augmented antioxidant activity in rats for the treatment of oxidative stress. This NG exhibited excellent stability and sustained release of the drug with outstanding antioxidant activity which could be attributed to the increase solubility of the drug and augmented permeability from the NG [94].

4.4. Diabetes Management. Diabetes, a very prevailing chronic disease around the globe, has grabbed the attention of scientists, and new ways of its management are reported. Recently, a new improved therapeutic regimen, noninvasive glucose checking techniques, and new methods of insulin administration have been reported $[95,96]$. In this aspect, the preparation of glucose-sensitive NGs has addressed the major hurdles linked with diabetes management. Most particularly, these NGs exhibited sustained release of the insulin by glucose-dependent swelling and shrinking mechanisms $[97,98]$.

4.5. Cancer Therapy. Various anticancer drugs, e.g., doxorubicin, cisplatin, 5-fluorouracil, and temozolomide, can be incorporated in NGs for the treatment of cancer. Temperature- and $\mathrm{pH}$-sensitive hydrogels of doxorubicin based on maleic acid poly-(N-isopropyl acrylamide) polymer were used in cancer therapy in which doxorubicin release was dependent on temperature and $\mathrm{pH}$. Chitin-based NG of doxorubicin can be used for various types of cancers including lungs, breast, liver, and prostate cancer [99]. Similarly, photosensitizer agent chlorin e6 has been recently used for the photodynamic therapy of cancer using chitosan-based NGs [100]. A descriptive detail of the anticancer applications of NGs is given in Table 1.

4.6. Tissue Engineering and Gene Therapy. NG-based formulations are widely used for tissue engineering and gene therapy. They are also used to deliver enzymes, genes, and proteins at a targeted site to achieve their intended effects. Artificial chaperons are usually utilized to modify polymers to carry enzymes and proteins. Similarly, pullulan is chemically modified by conjugating cholesterol moieties, and the functionalized molecules are self-assembled in water to develop NGs of up to $30 \mathrm{~nm}$ size. These NGs have an extraordinary biocompatibility which is utilized for bone regeneration $[101,102]$. The properties usually depend on their size and density of NGs which alternatively depend upon the degree of substitution of the cholesterol fragments in NGs. Some of the NG formulations used in transport of enzymes, genes, and proteins are as follows (Table 2).

4.7. Inflammatory Disorders. NGs are considered as important delivery systems for various anti-inflammatory agents. For instance, siRNA-loaded NGs were prepared by polymerization and chemical cross-linking. Structurally, it was polymethacrylic acid-co-N-vinyl-2-pyrrolidone (P[MAAco-NVP]) cross-linked with a trypsin-degradable peptide linker. A maximum amount of drug was released in the intestinal environment due to its $\mathrm{pH}$ and enzyme sensitivity and hence proved to be a suitable candidate for the treatment of inflammatory bowel disease [103]. Similarly, two antiinflammatory drugs spantide II and ketoprofen were loaded with (HPMC) and Carbopol-based NGs to achieve enhanced percutaneous delivery for the treatment of skin inflammation [104]. Additionally, anti-TNF $\alpha$ agent etanercept (ETR) was recently loaded with thermoresponsive NGs which not only resulted in effective delivery but showed enhanced antiinflammatory responses [105].

The NGs enhanced their ability to get deposited in skin's epidermis and dermis for the therapy of topical inflammatory diseases. They are prepared by either solvent evaporation or emulsification method [106]. Photosensitizers tetraphenylporphyrin tetrasulfonate (TPPS 4 ), tetra-phenyl-chlorintetra-carboxylate $\left(\mathrm{TPCC}_{4}\right)$, and chlorin e6 (Ce6) have a hyaluronate ligand-gated chitosan with tripolyphosphate (TPP) as a cross-linker in their structure. Their potential for extending the retention time and reducing clearance from the inflamed joints enlists NGs as real contenders for the selective delivery of photosensitizers to macrophages. Ionic gelation is the method applied in their preparation [107]. Activated NGs of methotrexate have copolymerized Nisopropylacrylamide (NIPAM) and BA (poly(NIPAM-co$\mathrm{BA})$ ) polymers in its composition. It is synthesized by the emulsion polymerization method. Their advantages include amplified release, elevated concentration gradient, building 
TABLe 1: Anticancer applications of NGs.

\begin{tabular}{|c|c|c|c|c|c|}
\hline NG composition & Type of NG & Drug used & $\begin{array}{l}\text { Method of } \\
\text { preparation }\end{array}$ & Results and applications & References \\
\hline PVA (polyvinyl alcohol) & $\begin{array}{l}\text { Charge } \\
\text { conversional and } \\
\text { reduction- } \\
\text { sensitive NG }\end{array}$ & Doxorubicin & $\begin{array}{c}\text { Inverse } \\
\text { nanoprecipitation }\end{array}$ & $\begin{array}{c}\text { Better cell toxicity. } \\
\text { Improved targeted intracellular } \\
\text { drug release. }\end{array}$ & {$[114]$} \\
\hline $\begin{array}{l}\text { Dextrin with formaldehyde } \\
\text { as a cross-linker }\end{array}$ & pH-sensitive NG & Doxorubicin & $\begin{array}{l}\text { Emulsion cross- } \\
\text { linking method }\end{array}$ & $\begin{array}{l}\text { Efficacious antitumor activity } \\
\text { It is an important candidate for the } \\
\text { treatment of colorectal cancer. }\end{array}$ & {$[104]$} \\
\hline $\begin{array}{l}\text { Poly(ethylene glycol)-b- } \\
\text { poly(L-glutamic acid) } \\
\text { (PEG-b-PGA) }\end{array}$ & $\begin{array}{l}\text { Polypeptide- } \\
\text { based NG }\end{array}$ & $\begin{array}{l}\text { 17-AAG } \\
\text { Doxorubicin }\end{array}$ & $\begin{array}{l}\text { Cross-linking } \\
\text { method }\end{array}$ & $\begin{array}{l}\text { Improved anticancer activity } \\
\text { Effective cytotoxicity in a breast } \\
\text { cancer cell panel }\end{array}$ & {$[33,115]$} \\
\hline $\begin{array}{l}\mathrm{P}(\mathrm{N} \text {-isopropyl-acrylamide- } \\
\text { co-butyl methacrylates })\end{array}$ & $\begin{array}{l}\text { Temperature- } \\
\text { sensitive NG } \\
\text { dispersion }\end{array}$ & Doxorubicin & $\begin{array}{l}\text { Emulsion } \\
\text { polymerization } \\
\text { method }\end{array}$ & $\begin{array}{l}\text { Improved efficacy for transarterial } \\
\text { chemoembolization (TACE) of } \\
\text { iohexol dispersion (IBi-D) was } \\
\text { observed on rabbit VX2 liver tumors. }\end{array}$ & {$[116]$} \\
\hline $\begin{array}{l}\text { Poly (N- } \\
\text { isopropylmethacrylamide) } \\
\text { (PNiPMA), PDA-PEG, 4- } \\
\text { methoxybenzoic acid (MBA) }\end{array}$ & $\begin{array}{l}\mathrm{pH}, \text { thermal, and } \\
\text { redox potential } \\
\text { triple-responsive } \\
\text { expansile } \mathrm{NG} \\
\text { (TRN) }\end{array}$ & Pc 4 & & $\begin{array}{l}\text { Targeted delivery of pc } 4 \text { to sigma } 2 \\
\text { receptors in head and neck tumors. }\end{array}$ & [117] \\
\hline $\begin{array}{l}\text { Glycol chitosan (GC) } \\
\text { conjugated with 2,3- } \\
\text { dimethylmaleic acid (dma) } \\
\text { and fullerene (C60) conjugate } \\
\text { (GC-g-DMA-g-C60) }\end{array}$ & $\begin{array}{l}\text { Acid } \mathrm{pH}- \\
\text { responsive } \mathrm{NG}\end{array}$ & $\begin{array}{l}\text { Photosensitizer } \\
\text { drug }\end{array}$ & $\begin{array}{l}\text { Two-step } \\
\text { chemical grafting } \\
\text { reaction }\end{array}$ & $\begin{array}{l}\text { Beneficial to target endosomes and } \\
\text { in vivo photodynamic therapy in } \\
\text { different types of malignant tumors. }\end{array}$ & [118] \\
\hline $\begin{array}{l}\text { Dextrin with glyoxal as a } \\
\text { cross-linker }\end{array}$ & pH-sensitive NG & Doxorubicin & $\begin{array}{l}\text { Emulsion cross- } \\
\text { linking method }\end{array}$ & $\begin{array}{l}\text { Rapid release effective internalization } \\
\text { of doxorubicin. } \\
\text { Reduced side effects to } \\
\text { cardiomyocytes and stem cells. }\end{array}$ & [119] \\
\hline Chitin poly (L-lactic acid) & $\begin{array}{l}\mathrm{pH} \text {-responsive } \\
\text { composite NG }\end{array}$ & Doxorubicin & & $\begin{array}{c}\text { Blood compatibility of the system } \\
\text { was confirmed by in vitro } \\
\text { coagulation assay and hemolytic } \\
\text { assay. } \\
\text { Effective for the treatment of liver } \\
\text { cancer. }\end{array}$ & [120] \\
\hline Chitin & pH-sensitive NG & 5-Fluorouracil & $\begin{array}{l}\text { Controlled } \\
\text { regeneration } \\
\text { chemistry } \\
\text { method }\end{array}$ & $\begin{array}{l}\text { Loosening of the epidermis after its } \\
\text { interaction with negatively charged } \\
\text { chitin with no inflammation. } \\
\text { Important drug carriers for skin } \\
\text { cancer therapy. }\end{array}$ & [121] \\
\hline $\begin{array}{l}\text { Folic acid conjugated } \\
\text { poly(ethylene oxide)-b- } \\
\text { poly(methacrylic acid) }\end{array}$ & $\begin{array}{l}\text { Ligand-gated } \\
\text { polyelectrolyte } \\
\text { NG }\end{array}$ & Cisplatin & $\begin{array}{l}\text { Cross-linking } \\
\text { method }\end{array}$ & $\begin{array}{l}\text { In vivo anticancer effect strengthens } \\
\text { their use for the treatment of ovarian } \\
\text { cancer. }\end{array}$ & [122] \\
\hline $\begin{array}{l}\text { Acetylated chondroitin } \\
\text { sulfate }(C S)\end{array}$ & $\begin{array}{l}\text { Self-organizing } \\
\text { NG }\end{array}$ & Doxorubicin & Dialysis method & $\begin{array}{l}\text { Drug was internalized into the } \\
\text { cytoplasm through endocytosis. } \\
\text { Effective drug carrier for anticancer } \\
\text { therapy. }\end{array}$ & {$[70]$} \\
\hline $\begin{array}{l}\text { N-Isopropylacrylamide } \\
\text { (NIPAM), poly(ethylene } \\
\text { glycol) (PEG), poly(ethylene } \\
\text { glycol) methyl ether } \\
\text { methacrylate (mPEGMA) }\end{array}$ & $\begin{array}{l}\text { pH-thermal dual- } \\
\text { responsive NG }\end{array}$ & $\begin{array}{l}\text { Cisplatin } \\
\text { (CDDP) }\end{array}$ & $\begin{array}{l}\text { Emulsion } \\
\text { polymerization } \\
\text { method }\end{array}$ & $\begin{array}{l}\text { Extended circulation time. } \\
\text { Reduced side effects } \\
\text { Better antitumor activity for the } \\
\text { treatment of breast cancer. }\end{array}$ & [123] \\
\hline $\begin{array}{l}\text { In situ immobilization of CdSe } \\
\text { quantum dots in interior of } \\
\text { hydroxypropyl cellulose } \\
\text { poly(acrylic acid) (HPC-PAA) }\end{array}$ & $\begin{array}{l}\mathrm{pH} \text { and } \\
\text { temperature- } \\
\text { responsive NG }\end{array}$ & Temozolomide & $\begin{array}{l}\text { Polymerization } \\
\text { method }\end{array}$ & $\begin{array}{l}\text { High drug loading, better stability, } \\
\text { and pH-dependent sustained release. } \\
\text { Used in cell imaging and optical pH } \\
\text { sensing. }\end{array}$ & {$[32]$} \\
\hline
\end{tabular}


TABLE 2: Applications of NG tissue engineering and gene therapy.

\begin{tabular}{|c|c|c|c|c|c|}
\hline NG composition & Type of NG & Drug/agent used & $\begin{array}{l}\text { Method of } \\
\text { preparation }\end{array}$ & $\begin{array}{l}\text { Results and } \\
\text { applications }\end{array}$ & References \\
\hline CHOPA-PEGSH & Hybrid NG & W9 peptide & Cross-linking & $\begin{array}{c}\text { Bone repair, } \\
\text { sustained release }\end{array}$ & {$[124]$} \\
\hline $\begin{array}{l}\text { Pullulan-collagen; } 1,2,7,8- \\
\text { diepoxyoctane }\end{array}$ & PHD hybrid NG & 1,2,7,8-Diepoxyoctane & Cross-linking & Tissue filler materials & [125] \\
\hline $\begin{array}{l}\text { Dendritic polyglycerol (dPG) } \\
\text { and low-molecular-weight } \\
\text { polyethylenimine }\end{array}$ & $\mathrm{pH}$-sensitive $\mathrm{NG}$ & siRNA & $\begin{array}{l}\text { Thiol-Michael } \\
\text { nanoprecipitation } \\
\text { method }\end{array}$ & $\begin{array}{l}\text { In vitro gene } \\
\text { silencing. } \\
\text { Gene therapy }\end{array}$ & {$[126]$} \\
\hline $\begin{array}{l}\text { Chitosan-myristic acid } \\
\text { NG (CMA) }\end{array}$ & Cross-linked NG & Aryldialkylphosphatase & $\begin{array}{l}\text { "Self-assembly via } \\
\text { chemical } \\
\text { modification" } \\
\text { method }\end{array}$ & $\begin{array}{l}\text { Enhanced } \mathrm{pH} \text { and } \\
\text { thermal stability } \\
\text { Used for } \\
\text { detoxification of } \\
\text { paraoxon }\end{array}$ & {$[127]$} \\
\hline $\begin{array}{l}\text { Poly(N-isopropylacrylamide)- } \\
\text { polyglycerol }\end{array}$ & $\begin{array}{l}\text { Thermoresponsive } \\
\text { NG }\end{array}$ & Biomacromolecules & & $\begin{array}{l}\text { Enhanced stability } \\
\text { and release of protein } \\
\text { Effective for the } \\
\text { topical delivery of } \\
\text { biomacromolecules }\end{array}$ & {$[128]$} \\
\hline Poly(N-vinyl pyrrolidone) (PVP) & Functionalized NG & $\begin{array}{c}\text { Oligonucleotides } \\
\text { (ODN) }\end{array}$ & $\begin{array}{l}\text { Cross-linking and } \\
\text { polymerization }\end{array}$ & $\begin{array}{c}\text { Negligible } \\
\text { cytotoxicity } \\
\text { Bypass cellular } \\
\text { membranes } \\
\text { Effective } \\
\text { nanocarriers for gene } \\
\text { delivery }\end{array}$ & [129] \\
\hline Polyethyleneimine (PEI) & $\begin{array}{l}\text { Microenvironment- } \\
\text { responsive } \\
\text { functional NG }\end{array}$ & Gene & $\begin{array}{l}\text { Cross-linking and } \\
\text { polymerization }\end{array}$ & $\begin{array}{c}\text { Reduced cytotoxicity } \\
\text { Enhanced } \\
\text { transfection } \\
\text { efficiency } \\
\text { Potential gene } \\
\text { therapy }\end{array}$ & {$[106]$} \\
\hline $\begin{array}{l}\text { Poly(2-methacryloyloxyethyl } \\
\text { phosphorylcholine), } \\
\text { poly(methoxydiethylene glycol } \\
\text { methacrylate) } \\
\text { (poly(MeODEGM)) and poly } \\
\text { (2-aminoethyl methacrylamide } \\
\text { hydrochloride) (poly(AEMA)) }\end{array}$ & $\begin{array}{l}\text { Thermosensitive } \\
\text { NG }\end{array}$ & Protein & $\begin{array}{c}\text { Reversible addition } \\
\text {-fragmentation } \\
\text { chain transfer [56] } \\
\text { and polymerization } \\
\text { technique }\end{array}$ & $\begin{array}{l}\text { Temperature- } \\
\text { sensitive controlled } \\
\text { release of proteins } \\
\text { from biodegradable } \\
\text { NG }\end{array}$ & {$[130]$} \\
\hline $\begin{array}{l}\text { Enzymatically synthesized } \\
\text { glycogen (ESG) with } \\
\text { cholesterol group }\end{array}$ & Artificial chaperon & & $\begin{array}{l}\text { Hydrophobic } \\
\text { modification self- } \\
\text { assembly method }\end{array}$ & $\begin{array}{l}\text { Enhanced thermal } \\
\text { stability of enzyme } \\
\text { Used for biomedical } \\
\text { and protein } \\
\text { engineering }\end{array}$ & {$[131]$} \\
\hline $\begin{array}{l}\text { Cholesteryl group-bearing } \\
\text { pullulan (CHP) complexed with } \\
\text { methyl-b-cyclodextrin (M-b-CD) }\end{array}$ & Artificial chaperon & & & $\begin{array}{l}\text { Protein synthesis was } \\
\text { not affected. } \\
\text { Help in folding of } \\
\text { active proteins. }\end{array}$ & {$[132]$} \\
\hline
\end{tabular}

flux of methotrexate along with depressing $\mathrm{PGE}_{2}$ production, and hence effective anti-inflammatory effects [71, 108].

4.8. Pain Management. NGs have been successfully used for the local distribution of anesthetic medications for the pain management. They result in prolonged and sustained release of the incorporated drug [109]. Moreover, they resulted in lower cytotoxicity and enhanced drug uptake [110]. A detailed description of NGs as a local anesthetic drug delivery system is given in Table 3 .

4.9. Ophthalmic Diseases. NGs can be employed for ocular delivery with an advantage of enhanced residence time, controlled release of the loaded drug, increased corneal penetration, enhanced bioavailability, etc. These advantages offer improved patient compliance and also reduce dosing 
TABLE 3: NGs for the management of pain.

\begin{tabular}{|c|c|c|c|c|c|}
\hline NG composition & Type of NG & $\begin{array}{l}\text { Drug/agent } \\
\text { used }\end{array}$ & $\begin{array}{l}\text { Method of } \\
\text { preparation }\end{array}$ & Results and applications & References \\
\hline NIPAAM, MAA & Magnetic NG & Bupivacaine & $\begin{array}{l}\text { Free radical } \\
\text { emulsion } \\
\text { polymerization } \\
\text { method }\end{array}$ & $\begin{array}{c}\text { Rapid release at low } \\
\text { temperature } \\
\text { and } \mathrm{pH} \\
\text { Effective for the treatment } \\
\text { of ankle block }\end{array}$ & {$[133]$} \\
\hline $\begin{array}{l}\text { Pluronic F127, hyaluronic } \\
\text { acid (HA) }\end{array}$ & Thermogel & Bupivacaine & & $\begin{array}{l}\text { Easy to inject in situ gel for } \\
\text { localized affect sustained } \\
\text { release profile } \\
\text { Less cytotoxic }\end{array}$ & [109] \\
\hline Chitosan & Thermogel & Rupivacaine & & $\begin{array}{l}\text { Controlled release } \\
\text { Efficacious delivery system } \\
\text { for local anesthetic affect }\end{array}$ & {$[134]$} \\
\hline $\begin{array}{l}\text { Poly(N-isopropylacrylamide) } \\
\text { (PNIPAM) }\end{array}$ & $\begin{array}{l}\text { Temperature-sensitive } \\
\text { NG }\end{array}$ & Bupivacaine & Polymerization & $\begin{array}{l}\text { Less cytotoxic enhanced } \\
\text { drug uptake }\end{array}$ & {$[135]$} \\
\hline Alginate, chitosan & NG & Bupivacaine & & $\begin{array}{c}\text { Acceptable cytotoxicity } \\
\text { and stability } \\
\text { Slower drug release }\end{array}$ & {$[136]$} \\
\hline $\begin{array}{l}\text { Poly (e-caprolactone)-poly } \\
\text { (ethylene glycol)-poly } \\
\text { (e-caprolactone) } \\
\text { (PCL-PEG-PCL) } \\
\text { Pluronic F-127 }\end{array}$ & $\begin{array}{l}\text { Thermoresponsive } \\
\text { NG }\end{array}$ & Lidocaine & $\begin{array}{c}\text { Emulsion solvent } \\
\text { evaporation } \\
\text { method }\end{array}$ & $\begin{array}{l}\text { Prolonged anesthetic affect } \\
\text { with lesser toxicity } \\
\text { Enhanced retention of } \\
\text { local anesthetic }\end{array}$ & {$[137]$} \\
\hline $\begin{array}{l}\text { Methacrylic acid-ethyl acrylate } \\
\text { cross-linked with diallyl phthalate }\end{array}$ & $\mathrm{pH}$-sensitive NG & Bupivacaine & $\begin{array}{c}\text { Emulsion } \\
\text { polymerization }\end{array}$ & $\begin{array}{l}\text { Enhanced } \mathrm{pH} \text {-dependent } \\
\text { anesthetic affect }\end{array}$ & {$[138]$} \\
\hline
\end{tabular}

TABLE 4: NGs for ophthalmic delivery.

\begin{tabular}{|c|c|c|c|c|c|}
\hline NG composition & Type of NG & Drug/agent used & Method of preparation & Results and applications & References \\
\hline $\begin{array}{l}\text { Nanodiamond, chitosan, } \\
\text { poly(hydroxy ethyl } \\
\text { methacrylate) matrix }\end{array}$ & Diamond NG & Timolol maleate & $\begin{array}{l}\text { Spontaneous } \\
\text { cluster formation }\end{array}$ & $\begin{array}{l}\text { Lysozyme mediated sustained release } \\
\text { Enhanced retention in the eye } \\
\text { Localized delivery to treat glaucoma }\end{array}$ & [139] \\
\hline $\begin{array}{l}\text { Polyvinylpyrrolidone and } \\
\text { acrylic acid (AAc) }\end{array}$ & NG & Pilocarpine & $\begin{array}{l}\gamma \text { radiation-induced } \\
\text { Polymerization }\end{array}$ & $\begin{array}{l}\text { Sustained drug release and improved } \\
\text { bioavailability response }\end{array}$ & {$[140]$} \\
\hline PLGA, chitosan & In situ NG & Levofloxacin & & $\begin{array}{l}\text { Sustained drug release } \\
\text { Enhanced corneal retention } \\
\text { Slow drug clearance }\end{array}$ & [141] \\
\hline Chitin & NG & Fluconazole & $\begin{array}{l}\text { Controlled } \\
\text { regeneration } \\
\text { chemistry method }\end{array}$ & $\begin{array}{l}\text { Good penetration to the cornea } \\
\text { Effective for the treatment of corneal } \\
\text { fungal infection }\end{array}$ & {$[142]$} \\
\hline Cyclodextrin & NG & Dexamethasone & $\begin{array}{l}\text { Emulsion-solvent } \\
\text { Evaporation }\end{array}$ & $\begin{array}{l}\text { Controlled drug release by adhering } \\
\text { to the ocular surface. } \\
\text { Enhanced ocular bioavailability. } \\
\text { Extended drug retention at eye surface }\end{array}$ & {$[143]$} \\
\hline PLA, sodium alginate & In situ NG & 5-Fluorouracil & $\begin{array}{l}\text { Emulsion-solvent } \\
\text { Evaporation }\end{array}$ & $\begin{array}{l}\text { Controlled drug release } \\
\text { Enhanced retention of gel } \\
\text { Effective ophthalmic delivery system for } \\
\text { the treatment of conjunctival/corneal } \\
\text { squamous cell carcinoma (CCSC) }\end{array}$ & {$[144]$} \\
\hline $\begin{array}{l}N \text {-Isopropyl acrylamide, } \\
\text { 2-hydroxy-methacrylate } \\
\text { Lactide-dextran }\end{array}$ & & Tacrolimus & & $\begin{array}{l}\text { Sustained drug release profile } \\
\text { Increased penetration to the cornea }\end{array}$ & {$[98]$} \\
\hline
\end{tabular}


frequency. Some of the ophthalmic applications of NGs are given below (Table 4).

4.10. Autoimmune Diseases. Autoimmune diseases can be effectively treated by using NG systems loaded with agents to be delivered to antigen-presenting cells to produce autoimmune responses. NGs containing KN93 and mycophenolic acid as therapeutic moieties are prepared by cross-linking and polymerization of the diacrylate-terminated co-block polymer of poly(lactic acid-co-ethylene glycol), CD [111]. The former specifically targeted CD4+T cells and reduced experimental autoimmune encephalomyelitis while later becoming effective for treating lupus by reducing cytokine production and enhancing immunosuppression $[112,113]$.

\section{Conclusion}

The vehicle for drug delivery may have numerous components that need to be effectual, productive, and finely tuned. NGs are versatile and attractive delivery systems having combined attributes of both nanoparticles and hydrogel. Ease in synthesis and purification of this delivery system provides exceptional drug encapsulation efficiency, response to numerous environmental stimuli, higher level of stability, and biologic consistency as compared to other delivery systems, also allowing for convenient functionalization to target cells. The size control for several applications in the delivery of drugs can be tailor-made for lesser cytotoxic with unique and versatile fabrication of NGs by designing a nontoxic delivery vehicle which become metabolized into harmless components in the body. NGs are proficiently internalized by the target cells, avoid accumulation in nontarget tissues, and thereby lower the therapeutic dosage and minimize harmful side effects. The effectiveness and compatibility are enhanced multifolds by the NG delivery system with safety mostly for hydrophilic, hydrophobic, and small drug molecules due to their chemical conformation and formulations that are unsuitable for other preparations. These minute transporters can also hold an amalgamation of purpose depending on two or more agents for diagnosis, imaging, controlled release, and site-specific targeting. These practicalities of NGs have unlocked the opportunities for more development in the field of biomedical applications and drug delivery.

5.1. Future Perspectives. Nanomaterials have gained increased clinical interest in recent times on account of a drastic need for improvements in conventional drug delivery and diagnostic tools. Drug delivery scientists over the past three decades have extensively investigated various nanomaterials for drug delivery applications. Owing to their extremely small size with large surface area, these nanomaterials have produced delivery systems with altered basic properties and bioactivity of drug cargos, improved pharmacokinetics, reduced toxicity, controlled drug release, and targeted delivery of therapeutics. In this context, NGs offer versatile platforms with combined properties of crosslinking gelling materials and nanotechnology. Hydrogel properties improve the physicochemical characteristics of
NGs, while nanometric size facilitates their transport and biodistribution in different sites of the body. NG technology has earned a wide use in biomedicine ranging from drug delivery to tissue engineering, from imaging to diagnosis and biosensing. Surface functionalization and stimulus responsiveness have added a lot to the advantages and applications of NGs.

A widespread application and versatility of NGs hold them with a great potential for future innovative research to cover the yet unmet needs. A tremendous amount of research is currently in progress to design and fabricate NGs with novel polymers to have more control over the release of their payloads. Likewise, a multitude of preparation techniques have been explored in the past few years to synthesize NGs with the desired set of attributes for various applications. Targeted delivery of NGs by surface functionalization is an area that still has a lot of potential for research in the days to come. However, antibody-conjugated NGs have newly been developed for the targeted delivery of anticancer drugs. However, targeting only a single cancer antigen is improbable because of the heterogeneous expression of cancer antigens in tumor sites. Development of multitargeted NG systems will result in superior cancer diagnostics and therapeutics. Furthermore, a design of NGs in terms of high uptake in selected cancer cells needs to be improved through the collaboration of polymer chemists and biologists. They can elucidate the specific interactions of biomolecules and receptors, which are then prudently attached to NG systems for a more precise targeted delivery. Investigation is required to determine the mechanisms of uptake of NGs at the neuron and/or glial cell level within the central nervous system. It will confirm that NGs prefer a cytosolic destination over an endosomal target. This sort of studies is essential if NGs are ever to be projected as specific drug delivery systems for targeting at the subcellular level.

Whereas NGs have provided a substantial advancement in the current drug delivery and therapeutic and diagnostic tools, a number of shortcomings need urgent attention. Development of cost-effective methods and resolution of technological issues are required for a large-scale production of NGs. A number of questions pertaining to pharmacokinetics and pharmacodynamics need to be answered. Provided these shortcomings are satisfied, NGs can translate into efficient next-generation pharmaceuticals with enhanced clinical care in the near future.
Abbreviations
NGs:
Nanogels
API:
PEI:
PEG:
PEG-CL-PEI:
Active pharmaceutical ingredient
Polyethyleneimine
Polyethylene glycol
QDs:
Cross-linked polyethylene glycol
polyethyleneimine
PDS:
UV:
Quantum dots
Pyridyl disulfide
Ultraviolet
CHP:
Cholesterol-based pullulan
HPMC: 


$\begin{array}{ll}\text { A } \beta: & \text { Amyloid } \beta \text {-protein } \\ \text { MI: } & \text { Myocardial infarction } \\ \text { NMR: } & \text { Nuclear magnetic resonance } \\ \text { NIPA: } & \text { N-Isopropylacrylamide } \\ \text { RAFT: } & \text { Reversible addition fragmentation chain } \\ & \text { transfer } \\ \text { g-PEGs: } & \text { Oligo polymer ethylene glycol } \\ \text { P[MAA-co-NVP]: } & \text { Polymethacrylic acid-co-N-vinyl-2- } \\ & \text { pyrrolidone } \\ \text { PLGA: } & \text { Poly lactic-co-glycolic acid } \\ \text { TPPS4: } & \text { Tetra-phenyl-porphyrin-tetra-sulfonate } \\ \text { TPCC4: } & \text { Tetra-phenyl-chlorin-tetra-carboxylate } \\ \text { TPP: } & \text { Tripolyphosphate } \\ \text { BA: } & \text { Butyl acrylate } \\ \text { CHA: } & \text { Cholesterol-bearing pullulan } \\ \text { CHOPA: } & \text { Acryloyl group-modified cholesterol- } \\ & \text { bearing pullulan } \\ \text { PEGSH: } & \text { Pentaerythritol tetra (mercaptoethyl) } \\ & \text { polyoxyethylene. }\end{array}$

\section{Conflicts of Interest}

The authors declare that they have no conflicts of interest.

\section{Authors' Contributions}

Fakhara Sabir and Imran Asad contributed equally to this work.

\section{References}

[1] M. Mir, S. Ishtiaq, S. Rabia et al., "Nanotechnology: from in vivo imaging system to controlled drug delivery," Nanoscale Research Letters, vol. 12, no. 1, p. 500, 2017.

[2] F. ud Din, D. W. Kim, J. Y. Choi et al., "Irinotecan-loaded double-reversible thermogel with improved antitumor efficacy without initial burst effect and toxicity for intramuscular administration," Acta Biomaterialia, vol. 54, pp. 239-248, 2017.

[3] F. ud Din, J. Y. Choi, D. W. Kim et al., "Irinotecan-encapsulated double-reverse thermosensitive nanocarrier system for rectal administration," Drug Delivery, vol. 24, no. 1 , pp. 502-510, 2017.

[4] A. J. Sivaram, P. Rajitha, S. Maya, R. Jayakumar, and M. Sabitha, "Nanogels for delivery, imaging and therapy," Wiley Interdisciplinary Reviews: Nanomedicine and Nanobiotechnology, vol. 7, no. 4, pp. 509-533, 2015.

[5] W. N. Charman, H. K. Chan, B. C. Finnin, and S. A. Charman, "Drug delivery: a key factor in realising the full therapeutic potential of drugs," Drug Development Research, vol. 46, no. 3-4, pp. 316-327, 1999.

[6] K. S. Soppimath, T. M. Aminabhavi, A. R. Kulkarni, and W. E. Rudzinski, "Biodegradable polymeric nanoparticles as drug delivery devices," Journal of Controlled Release, vol. 70, no. 1-2, pp. 1-20, 2001.

[7] T. Garg, R. S. R. Murthy, A. Kumar Goyal, S. Arora, and B. Malik, "Development, optimization \& evaluation of porous chitosan scaffold formulation of gliclazide for the treatment of type-2 diabetes mellitus," Drug Delivery Letters, vol. 2, no. 4, pp. 251-261, 2012.
[8] S. V. Vinogradov, T. K. Bronich, and A. V. Kabanov, "Nanosized cationic hydrogels for drug delivery: preparation, properties and interactions with cells," Advanced Drug Delivery Reviews, vol. 54, no. 1, pp. 135-147, 2002.

[9] Y. Murali Mohan, M. Reddy, and V. Labhasetwar, Nanogels: Chemistry to Drug Delivery, John Wiley \& Sons, Inc, New Jersey, 2007.

[10] M. M. Yallapu, M. Jaggi, and S. C. Chauhan, "Design and engineering of nanogels for cancer treatment," Drug Discovery Today, vol. 16, no. 9-10, pp. 457-463, 2011.

[11] S. A. Bencherif, D. J. Siegwart, A. Srinivasan et al., "Nanostructured hybrid hydrogels prepared by a combination of atom transfer radical polymerization and free radical polymerization," Biomaterials, vol. 30, no. 29, pp. 5270-5278, 2009.

[12] E. Bilensoy, Cyclodextrins in Pharmaceutics, Cosmetics, and Biomedicine: Current and Future Industrial Applications, John Wiley \& Sons, 2011.

[13] A. Vintiloiu and J.-C. Leroux, "Organogels and their use in drug delivery-a review," Journal of Controlled Release, vol. 125, no. 3, pp. 179-192, 2008.

[14] A. V. Kabanov and S. V. Vinogradov, "Nanogels as pharmaceutical carriers: finite networks of infinite capabilities," Angewandte Chemie International Edition, vol. 48, no. 30, pp. 5418-5429, 2009.

[15] K. S. Soni, S. S. Desale, and T. K. Bronich, "Nanogels: an overview of properties, biomedical applications and obstacles to clinical translation," Journal of Controlled Release, vol. 240, pp. 109-126, 2016.

[16] M. Cegnar, J. Kristl, and J. Kos, "Nanoscale polymer carriers to deliver chemotherapeutic agents to tumours," Expert Opinion on Biological Therapy, vol. 5, no. 12, pp. 1557-1569, 2005.

[17] P. Bawa, V. Pillay, Y. E. Choonara, and L. C. du Toit, "Stimuli-responsive polymers and their applications in drug delivery," Biomedical Materials, vol. 4, no. 2, article 022001, 2009.

[18] S.-i. Sawada, Y. Sasaki, Y. Nomura, and K. Akiyoshi, "Cyclodextrin-responsive nanogel as an artificial chaperone for horseradish peroxidase," Colloid and Polymer Science, vol. 289, no. 5-6, pp. 685-691, 2011.

[19] N. S. Zarekar, V. J. Lingayat, and V. V. Pande, "Nanogel as a novel platform for smart drug delivery system," Nanoscience and Nanotechnology, vol. 4, no. 1, pp. 25-31, 2017.

[20] M. Karimi, M. Eslami, P. Sahandi-Zangabad et al., "pHsensitive stimulus-responsive nanocarriers for targeted delivery of therapeutic agents," Wiley Interdisciplinary Reviews: Nanomedicine and Nanobiotechnology, vol. 8, no. 5, pp. 696-716, 2016.

[21] M. Qindeel, N. Ahmed, F. Sabir, S. Khan, and A. Ur-Rehman, "Development of novel pH-sensitive nanoparticles loaded hydrogel for transdermal drug delivery," Drug Development and Industrial Pharmacy, vol. 45, no. 4, pp. 629-641, 2019.

[22] M. S. Strozyk, S. Carregal-Romero, M. Henriksen-Lacey, M. Brust, and L. M. Liz-Marzán, "Biocompatible, multiresponsive nanogel composites for codelivery of antiangiogenic and chemotherapeutic agents," Chemistry of Materials, vol. 29, no. 5, pp. 2303-2313, 2017.

[23] H. Arya, Z. Kaul, R. Wadhwa, K. Taira, T. Hirano, and S. C. Kaul, "Quantum dots in bio-imaging: revolution by the small," Biochemical and Biophysical Research Communications, vol. 329, no. 4, pp. 1173-1177, 2005. 
[24] A. Phatak Atul and D. Chaudhari Praveen, "Development and evaluation of nanogel as a carrier for transdermal delivery of aceclofenac," Asian Journal of Pharmacy and Technology, vol. 2, no. 4, pp. 125-132, 2012.

[25] N. Singh, V. Gill, and P. Gill, "Nanogel based artificial chaperone technology: an overview," American Journal of Advanced Drug Delivery, vol. 1, no. 3, pp. 271-276, 2013.

[26] A. Sharma, T. Garg, A. Aman et al., "Nanogel—an advanced drug delivery tool: current and future," Artificial Cells, Nanomedicine, and Biotechnology, vol. 44, no. 1, pp. 165-177, 2016.

[27] H. Kobayashi, O. Katakura, N. Morimoto, K. Akiyoshi, and S. Kasugai, "Effects of cholesterol-bearing pullulan (CHP)nanogels in combination with prostaglandin E1 on wound healing," Journal of Biomedical Materials Research Part B: Applied Biomaterials, vol. 91B, no. 1, pp. 55-60, 2009.

[28] I. Taniguchi, K. Akiyoshi, J. Sunamoto, Y. Suda, and M. Yamamoto, "Cell specificity of macromolecular assembly of cholesteryl and galactoside groups-conjugated pullulan," Journal of Bioactive and Compatible Polymers, vol. 14, no. 3, pp. 195-212, 1999.

[29] K. Akiyoshi, "Hydrogel nanoparticle formed by self-assembly hydrophobized polysaccharide. Stabilization of adriamycin by complexation," European Journal of Pharmaceutics and Biopharmaceutics, vol. 42, pp. 286-290, 1996.

[30] K. Akiyoshi, S. Kobayashi, S. Shichibe et al., "Self-assembled hydrogel nanoparticle of cholesterol-bearing pullulan as a carrier of protein drugs: complexation and stabilization of insulin," Journal of Controlled Release, vol. 54, no. 3, pp. 313-320, 1998.

[31] Y. Ikuta, N. Katayama, L. Wang et al., "Presentation of a major histocompatibility complex class 1-binding peptide by monocyte-derived dendritic cells incorporating hydrophobized polysaccharide-truncated HER2 protein complex: implications for a polyvalent immuno-cell therapy," Blood, vol. 99, no. 10, pp. 3717-3724, 2002.

[32] W. Wu, M. Aiello, T. Zhou, A. Berliner, P. Banerjee, and S. Zhou, "In-situ immobilization of quantum dots in polysaccharide-based nanogels for integration of optical $\mathrm{pH}$-sensing, tumor cell imaging, and drug delivery," Biomaterials, vol. 31, no. 11, pp. 3023-3031, 2010.

[33] A. M. Derfus, W. C. W. Chan, and S. N. Bhatia, "Intracellular delivery of quantum dots for live cell labeling and organelle tracking," Advanced Materials, vol. 16, no. 12, pp. 961-966, 2004.

[34] Y. Nomura, M. Ikeda, N. Yamaguchi, Y. Aoyama, and K. Akiyoshi, "Protein refolding assisted by self-assembled nanogels as novel artificial molecular chaperone," FEBS Letters, vol. 553, no. 3, pp. 271-276, 2003.

[35] R. Gref, C. Amiel, K. Molinard et al., "New self-assembled nanogels based on host-guest interactions: characterization and drug loading," Journal of Controlled Release, vol. 111, no. 3, pp. 316-324, 2006.

[36] J. E. Wong and W. Richtering, "Layer-by-layer assembly on stimuli-responsive microgels," Current Opinion in Colloid \& Interface Science, vol. 13, no. 6, pp. 403-412, 2008.

[37] J. E. Wong, A. K. Gaharwar, D. Müller-Schulte, D. Bahadur, and W. Richtering, "Dual-stimuli responsive PNiPAM microgel achieved via layer-by-layer assembly: magnetic and thermoresponsive," Journal of Colloid and Interface Science, vol. 324, no. 1-2, pp. 47-54, 2008.
[38] J. E. Wong, A. M. Díez-Pascual, and W. Richtering, "Layer-by-layer assembly of polyelectrolyte multilayers on thermoresponsive $\mathrm{P}(\mathrm{NiPAM}-\mathrm{co}-\mathrm{MAA})$ microgel: effect of ionic strength and molecular weight," Macromolecules, vol. 42, no. 4, pp. 1229-1238, 2009.

[39] A. Charlot, V. Sciannaméa, S. Lenoir et al., "All-in-one strategy for the fabrication of antimicrobial biomimetic films on stainless steel," Journal of Materials Chemistry, vol. 19, no. 24, pp. 4117-4125, 2009.

[40] E. Faure, C. Falentin-Daudré, T. S. Lanero et al., "Functional nanogels as platforms for imparting antibacterial, antibiofilm, and antiadhesion activities to stainless steel," Advanced Functional Materials, vol. 22, no. 24, pp. 5271-5282, 2012.

[41] C. D. Jones and L. A. Lyon, "Synthesis and characterization of multiresponsive core- shell microgels," Macromolecules, vol. 33, no. 22, pp. 8301-8306, 2000.

[42] S. Schachschal, A. Balaceanu, C. Melian et al., "Polyampholyte microgels with anionic core and cationic shell," Macromolecules, vol. 43, no. 9, pp. 4331-4339, 2010.

[43] H. Park, L. O. Srisombat, A. Jamison et al., "Temperatureresponsive hydrogel-coated gold nanoshells," Gels, vol. 4, no. 2, p. 28, 2018.

[44] J. Yang, M. H. Yao, R. M. Jin, D. H. Zhao, Y. D. Zhao, and B. Liu, "Polypeptide-engineered hydrogel coated gold nanorods for targeted drug delivery and chemo-photothermal therapy," ACS Biomaterials Science \& Engineering, vol. 3, no. 10, pp. 2391-2398, 2017.

[45] W. Richtering and A. Pich, "The special behaviours of responsive core-shell nanogels," Soft Matter, vol. 8, no. 45, pp. 11423-11430, 2012.

[46] X. Li, B. Yang, S. Zhang, X. Jia, and Z. Hu, "Facile synthesis of hairy microparticle-/nanoparticle-supported MacMillan and its application to Diels-Alder reaction in water," Colloid and Polymer Science, vol. 295, no. 4, pp. 573-582, 2017.

[47] D. Li, X. Sheng, and B. Zhao, "Environmentally responsive "hairy" nanoparticles: mixed homopolymer brushes on silica nanoparticles synthesized by living radical polymerization techniques," Journal of the American Chemical Society, vol. 127, no. 17, pp. 6248-6256, 2005.

[48] J. Pyun, K. Matyjaszewski, T. Kowalewski et al., "Synthesis of well-defined block copolymers tethered to polysilsesquioxane nanoparticles and their nanoscale morphology on surfaces," Journal of the American Chemical Society, vol. 123, no. 38, pp. 9445-9446, 2001.

[49] A. A. Rudov, A. P. H. Gelissen, G. Lotze et al., "Intramicrogel complexation of oppositely charged compartments as a route to quasi-hollow structures," Macromolecules, vol. 50, no. 11, pp. 4435-4445, 2017.

[50] W.-H. Chiang, V. T. Ho, W. C. Huang, Y. F. Huang, C. S. Chern, and H. C. Chiu, "Dual stimuli-responsive polymeric hollow nanogels designed as carriers for intracellular triggered drug release," Langmuir, vol. 28, no. 42, pp. 1505615064, 2012.

[51] H. Xu, F. Meng, and Z. Zhong, "Reversibly crosslinked temperature-responsive nano-sized polymersomes: synthesis and triggered drug release," Journal of Materials Chemistry, vol. 19, no. 24, pp. 4183-4190, 2009.

[52] S. Nayak and L. A. Lyon, "Soft nanotechnology with soft nanoparticles," Angewandte Chemie International Edition, vol. 44, no. 47, pp. 7686-7708, 2005. 
[53] C. Donini, D. N. Robinson, P. Colombo, F. Giordano, and N. A. Peppas, "Preparation of poly (methacrylic acid-g-poly (ethylene glycol)) nanospheres from methacrylic monomers for pharmaceutical applications," International Journal of Pharmaceutics, vol. 245, no. 1-2, pp. 83-91, 2002.

[54] C. Laane, "Reverse micelles: biological and technological relevance of amphiphilic structures in apolar media: edited by P. L. Luisi and B. E. Straub, Plenum Press, 1984. $\$ 55.00$ (x + 354 pages) ISBN 030641620 4," Trends in Biotechnology, vol. 3, no. 1, p. 28, 1985.

[55] C. Booth and D. Attwood, "Effects of block architecture and composition on the association properties of poly (oxyalkylene) copolymers in aqueous solution," Macromolecular Rapid Communications, vol. 21, no. 9, pp. 501527, 2000.

[56] M. Look, E. Stern, Q. A. Wang et al., "Nanogel-based delivery of mycophenolic acid ameliorates systemic lupus erythematosus in mice," The Journal of Clinical Investigation, vol. 123, no. 4, pp. 1741-1749, 2013.

[57] L. Yan and W. Tao, "One-step synthesis of pegylated cationic nanogels of poly ( $\mathrm{N}, \mathrm{N}^{\prime}$-dimethylaminoethyl methacrylate) in aqueous solution via self-stabilizing micelles using an amphiphilic macroRAFT agent," Polymer, vol. 51, no. 10, pp. 2161-2167, 2010.

[58] E. Castro, S. Barbosa, J. Juárez, P. Taboada, I. A. Katime, and V. Mosquera, "Influence of external factors on the micellization process and aggregate structure of poly (oxy) styrenepoly (oxy) ethylene block copolymers," The Journal of Physical Chemistry B, vol. 112, no. 17, pp. 5296-5304, 2008.

[59] P. S. Denkova, L. V. Lokeren, I. Verbruggen, and R. Willem, "Self-aggregation and supramolecular structure investigations of triton X-100 and SDP2S by NOESY and diffusion ordered NMR spectroscopy," The Journal of Physical Chemistry B, vol. 112, no. 35, pp. 10935-10941, 2008.

[60] Y. Lin and P. Alexandridis, "Self-assembly of an amphiphilic siloxane graft copolymer in water," The Journal of Physical Chemistry B, vol. 106, no. 42, pp. 10845-10853, 2002.

[61] E. Kohli, H. Y. Han, A. D. Zeman, and S. V. Vinogradov, "Formulations of biodegradable nanogel carriers with 5 ' -triphosphates of nucleoside analogs that display a reduced cytotoxicity and enhanced drug activity," Journal of Controlled Release, vol. 121, no. 1-2, pp. 19-27, 2007.

[62] H. Mok and T. G. Park, "PEG-assisted DNA solubilization in organic solvents for preparing cytosol specifically degradable PEG/DNA nanogels," Bioconjugate Chemistry, vol. 17, no. 6, pp. 1369-1372, 2006.

[63] H. Sun, L. Y. Zhang, X. J. Zhu, C. Y. Kong, C. L. Zhang, and S. D. Yao, "Poly (PEGMA) magnetic nanogels: preparation via photochemical method, characterization and application as drug carrier," Science in China Series B: Chemistry, vol. 52, no. 1, pp. 69-75, 2009.

[64] Y. Gong, M. Fan, F. Gao et al., "Preparation and characterization of amino-functionalized magnetic nanogels via photopolymerization for MRI applications," Colloids and Surfaces B: Biointerfaces, vol. 71, no. 2, pp. 243-247, 2009.

[65] J. I. Lee, H. S. Kim, and H. S. Yoo, "DNA nanogels composed of chitosan and Pluronic with thermo-sensitive and photocrosslinking properties," International Journal of Pharmaceutics, vol. 373, no. 1-2, pp. 93-99, 2009.

[66] K. Raemdonck, B. Naeye, A. Høgset, J. Demeester, and S. C. de Smedt, "Prolonged gene silencing by combining siRNA nanogels and photochemical internalization," Journal of Controlled Release, vol. 145, no. 3, pp. 281-288, 2010.

[67] N. Alles, N. S. Soysa, M. D. A. Hussain et al., "Polysaccharide nanogel delivery of a TNF- $\alpha$ and RANKL antagonist peptide allows systemic prevention of bone loss," European Journal of Pharmaceutical Sciences, vol. 37, no. 2, pp. 83-88, 2009.

[68] U. Hasegawa, S. I. Sawada, T. Shimizu et al., "Raspberry-like assembly of cross-linked nanogels for protein delivery," Journal of Controlled Release, vol. 140, no. 3, pp. 312-317, 2009.

[69] B.-c. Bae and K. Na, "Self-quenching polysaccharide-based nanogels of pullulan/folate-photosensitizer conjugates for photodynamic therapy," Biomaterials, vol. 31, no. 24, pp. 6325-6335, 2010.

[70] W. Park, S.-j. Park, and K. Na, "Potential of self-organizing nanogel with acetylated chondroitin sulfate as an anticancer drug carrier," Colloids and Surfaces B: Biointerfaces, vol. 79, no. 2, pp. 501-508, 2010.

[71] G. S. L. Singka, N. A. Samah, M. H. Zulfakar, A. Yurdasiper, and C. M. Heard, "Enhanced topical delivery and antiinflammatory activity of methotrexate from an activated nanogel," European Journal of Pharmaceutics and Biopharmaceutics, vol. 76, no. 2, pp. 275-281, 2010.

[72] H. Hayashi, M. Iijima, K. Kataoka, and Y. Nagasaki, "pH-sensitive nanogel possessing reactive PEG tethered chains on the surface," Macromolecules, vol. 37, no. 14, pp. 5389-5396, 2004.

[73] D. Sikazwe, R. Yendapally, S. Ramsinghani, and M. Khan, "Alzheimer's drug discovery maze: a snap view of the past decade's diverse pharmacological targets for the disorder," Mini Reviews in Medicinal Chemistry, vol. 17, no. 3, pp. 305-318, 2017.

[74] J. W. Ashford, “Treatment of Alzheimer's disease: the legacy of the cholinergic hypothesis, neuroplasticity, and future directions," Journal of Alzheimer's Disease, vol. 47, no. 1, pp. 149-156, 2015.

[75] S.-H. Han, J.-C. Park, and I. Mook-Jung, "Amyloid $\beta$-interacting partners in Alzheimer's disease: from accomplices to possible therapeutic targets," Progress in Neurobiology, vol. 137, pp. 17-38, 2016.

[76] T. A. Bayer and O. Wirths, "Focusing the amyloid cascade hypothesis on N-truncated Abeta peptides as drug targets against Alzheimer's disease," Acta Neuropathologica, vol. 127, no. 6, pp. 787-801, 2014.

[77] Z. Jiang, X. Dong, X. Yan, Y. Liu, L. Zhang, and Y. Sun, "Nanogels of dual inhibitor-modified hyaluronic acid function as a potent inhibitor of amyloid $\beta$-protein aggregation and cytotoxicity," Scientific Reports, vol. 8, no. 1, p. 3505, 2018.

[78] Y. S. R. Elnaggar, S. M. Etman, D. A. Abdelmonsif, and O. Y. Abdallah, "Intranasal piperine-loaded chitosan nanoparticles as brain-targeted therapy in Alzheimer's disease: optimization, biological efficacy, and potential toxicity," Journal of Pharmaceutical Sciences, vol. 104, no. 10, pp. 35443556, 2015.

[79] S. Baltzley, A. Mohammad, A. H. Malkawi, and A. M. alGhananeem, "Intranasal drug delivery of olanzapine-loaded chitosan nanoparticles," AAPS PharmSciTech, vol. 15, no. 6, pp. 1598-1602, 2014.

[80] K.-L. Hu, N. Mei, L. Feng, and X.-G. Jiang, "Hydrophilic nasal gel of lidocaine hydrochloride," Arzneimittelforschung, vol. 59, no. 11, pp. 543-549, 2009. 
[81] S. M. Dange, M. S. Kamble, K. K. Bhalerao et al., "Formulation and evaluation of venlafaxine nanostructured lipid carriers," Journal of Bionanoscience, vol. 8, no. 2, pp. 81-89, 2014.

[82] D. Mozaffarian, E. J. Benjamin, A. S. Go et al., "Heart disease and stroke statistics-2015 update: a report from the american heart association," Circulation, vol. 131, no. 4, pp. e29-e322, 2015.

[83] K. Cheng, K. Malliaras, R. R. Smith et al., "Human cardiosphere-derived cells from advanced heart failure patients exhibit augmented functional potency in myocardial repair," JACC: Heart Failure, vol. 2, no. 1, pp. 49-61, 2014.

[84] K. Malliaras and E. Marbán, "Cardiac regeneration validated," Nature Biotechnology, vol. 33, no. 6, p. 587, 2015.

[85] M. M. Nguyen, N. C. Gianneschi, and K. L. Christman, "Developing injectable nanomaterials to repair the heart," Current Opinion in Biotechnology, vol. 34, pp. 225-231, 2015.

[86] J. Tang, X. Cui, T. G. Caranasos et al., "Heart repair using nanogel-encapsulated human cardiac stem cells in mice and pigs with myocardial infarction," ACS Nano, vol. 11, no. 10, pp. 9738-9749, 2017.

[87] C. C. Huang, Z. X. Liao, D. Y. Chen, C. W. Hsiao, Y. Chang, and H. W. Sung, "Injectable cell constructs fabricated via culture on a thermoresponsive methylcellulose hydrogel system for the treatment of ischemic diseases," Advanced Healthcare Materials, vol. 3, no. 8, pp. 1133-1148, 2014.

[88] H. E. Poulsen, “Oxidative DNA modifications," Experimental and Toxicologic Pathology, vol. 57, pp. 161-169, 2005.

[89] S. Ghibu, S. Delemasure, C. Richard et al., "General oxidative stress during doxorubicin-induced cardiotoxicity in rats: absence of cardioprotection and low antioxidant efficiency of alpha-lipoic acid," Biochimie, vol. 94, no. 4, pp. 932-939, 2012.

[90] A. Z. Wilczewska, K. Niemirowicz, K. H. Markiewicz, and H. Car, "Nanoparticles as drug delivery systems," Pharmacological Reports, vol. 64, no. 5, pp. 1020-1037, 2012.

[91] A. K. Jain, K. Thanki, and S. Jain, "Co-encapsulation of tamoxifen and quercetin in polymeric nanoparticles: implications on oral bioavailability, antitumor efficacy, and druginduced toxicity," Molecular Pharmaceutics, vol. 10, no. 9, pp. 3459-3474, 2013.

[92] P. P. Wattamwar, Y. Mo, R. Wan, R. Palli, Q. Zhang, and T. D. Dziubla, "Antioxidant activity of degradable polymer poly (trolox ester) to suppress oxidative stress injury in the cells," Advanced Functional Materials, vol. 20, no. 1, pp. 147-154, 2010.

[93] P. Gupta, S. P. Authimoolam, J. Z. Hilt, and T. D. Dziubla, "Quercetin conjugated poly ( $\beta$-amino esters) nanogels for the treatment of cellular oxidative stress," Acta Biomaterialia, vol. 27, pp. 194-204, 2015.

[94] R. K. Harwansh, P. K. Mukherjee, S. Bahadur, and R. Biswas, "Enhanced permeability of ferulic acid loaded nanoemulsion based gel through skin against UVA mediated oxidative stress," Life Sciences, vol. 141, pp. 202-211, 2015.

[95] R. M. DiSanto, V. Subramanian, and Z. Gu, "Recent advances in nanotechnology for diabetes treatment," Wiley Interdisciplinary Reviews: Nanomedicine and Nanobiotechnology, vol. 7, no. 4, pp. 548-564, 2015.

[96] F. J. Cameron and D. K. Wherrett, "Care of diabetes in children and adolescents: controversies, changes, and consensus," The Lancet, vol. 385, no. 9982, pp. 2096-2106, 2015.
[97] V. Lapeyre, C. Ancla, B. Catargi, and V. Ravaine, "Glucoseresponsive microgels with a core-shell structure," Journal of Colloid and Interface Science, vol. 327, no. 2, pp. 316-323, 2008.

[98] L. Zhao, C. Xiao, J. Ding et al., "Competitive bindingaccelerated insulin release from a polypeptide nanogel for potential therapy of diabetes," Polymer Chemistry, vol. 6, no. 20, pp. 3807-3815, 2015.

[99] R. Jayakumar, A. Nair, N. S. Rejinold, S. Maya, and S. V. Nair, "Doxorubicin-loaded $\mathrm{pH}$-responsive chitin nanogels for drug delivery to cancer cells," Carbohydrate Polymers, vol. 87, no. 3, pp. 2352-2356, 2012.

[100] Y.-F. Ding, S. Li, L. Liang et al., "Highly biocompatible chlorin e6-loaded chitosan nanoparticles for improved photodynamic cancer therapy," ACS Applied Materials \& Interfaces, vol. 10, no. 12, pp. 9980-9987, 2018.

[101] S. Boridy, H. Takahashi, K. Akiyoshi, and D. Maysinger, "The binding of pullulan modified cholesteryl nanogels to $\mathrm{A} \beta$ oligomers and their suppression of cytotoxicity," Biomaterials, vol. 30, no. 29, pp. 5583-5591, 2009.

[102] M. R. Rekha and C. P. Sharma, "Blood compatibility and in vitro transfection studies on cationically modified pullulan for liver cell targeted gene delivery," Biomaterials, vol. 30, no. 34, pp. 6655-6664, 2009.

[103] J. M. Knipe, L. E. Strong, and N. A. Peppas, "Enzyme-and $\mathrm{pH}$-responsive microencapsulated nanogels for oral delivery of siRNA to induce TNF- $\alpha$ knockdown in the intestine," Biomacromolecules, vol. 17, no. 3, pp. 788-797, 2016.

[104] P. P. Shah, P. R. Desai, A. R. Patel, and M. S. Singh, "Skin permeating nanogel for the cutaneous co-delivery of two anti-inflammatory drugs," Biomaterials, vol. 33, no. 5, pp. 1607-1617, 2012.

[105] M. Giulbudagian, G. Yealland, S. Hönzke et al., "Breaking the barrier-potent anti-inflammatory activity following efficient topical delivery of etanercept using thermoresponsive nanogels," Theranostics, vol. 8, no. 2, pp. 450463, 2018.

[106] B. Shi, H. Zhang, S. Z. Qiao, J. Bi, and S. Dai, "Intracellular microenvironment-responsive label-free autofluorescent nanogels for traceable gene delivery," Advanced Healthcare Materials, vol. 3, no. 11, pp. 1839-1848, 2014.

[107] Y. Sasaki, Y. Nomura, S. I. Sawada, and K. Akiyoshi, "Polysaccharide nanogel-cyclodextrin system as an artificial chaperone for in vitro protein synthesis of green fluorescent protein," Polymer Journal, vol. 42, no. 10, pp. 823-828, 2010.

[108] T. Shiokawa, Y. Hattori, K. Kawano et al., "Effect of polyethylene glycol linker chain length of folate-linked microemulsions loading aclacinomycin A on targeting ability and antitumor effect in vitro and in vivo," Clinical Cancer Research, vol. 11, no. 5, pp. 2018-2025, 2005.

[109] D. Seol, M. J. Magnetta, P. S. Ramakrishnan et al., "Biocompatibility and preclinical feasibility tests of a temperaturesensitive hydrogel for the purpose of surgical wound pain control and cartilage repair," Journal of Biomedical Materials Research Part B: Applied Biomaterials, vol. 101, no. 8, pp. 1508-1515, 2013.

[110] T. Hoare, D. Sivakumaran, C. F. Stefanescu, M. W. Lawlor, and D. S. Kohane, "Nanogel scavengers for drugs: local anesthetic uptake by thermoresponsive nanogels," Acta Biomaterialia, vol. 8, no. 4, pp. 1450-1458, 2012. 
[111] H. Raghu, C. M. Lepus, Q. Wang et al., "CCL2/CCR2, but not CCL5/CCR5, mediates monocyte recruitment, inflammation and cartilage destruction in osteoarthritis," Annals of the Rheumatic Diseases, vol. 76, no. 5, pp. 914-922, 2017.

[112] R. S. Redis, A. M. Sieuwerts, M. P. Look et al., "CCAT2, a novel long non-coding RNA in breast cancer: expression study and clinical correlations," Oncotarget, vol. 4, no. 10, pp. 1748-1762, 2013.

[113] K. Otomo, T. Koga, M. Mizui et al., "Cutting edge: nanogelbased delivery of an inhibitor of CaMK4 to CD4+ T cells suppresses experimental autoimmune encephalomyelitis and lupus-like disease in mice," The Journal of Immunology, vol. 195, no. 12, pp. 5533-5537, 2015.

[114] W. Chen, K. Achazi, B. Schade, and R. Haag, "Charge-conversional and reduction-sensitive poly (vinyl alcohol) nanogels for enhanced cell uptake and efficient intracellular doxorubicin release," Journal of Controlled Release, vol. 205, pp. 15-24, 2015.

[115] S. S. Desale, S. M. Raja, J. O. Kim et al., "Polypeptide-based nanogels co-encapsulating a synergistic combination of doxorubicin with 17-AAG show potent anti-tumor activity in ErbB2-driven breast cancer models," Journal of Controlled Release, vol. 208, pp. 59-66, 2015.

[116] K. Qian, Y. Ma, J. Wan et al., "The studies about doxorubicinloaded p (N-isopropyl-acrylamide-co-butyl methylacrylate) temperature-sensitive nanogel dispersions on the application in TACE therapies for rabbit VX2 liver tumor," Journal of Controlled Release, vol. 212, pp. 41-49, 2015.

[117] H. He, A. W. Cattran, T. Nguyen, A. L. Nieminen, and P. Xu, "Triple-responsive expansile nanogel for tumor and mitochondria targeted photosensitizer delivery," Biomaterials, vol. 35, no. 35, pp. 9546-9553, 2014.

[118] S. Kim, D. J. Lee, D. S. Kwag, U. Y. Lee, Y. S. Youn, and E. S. Lee, "Acid pH-activated glycol chitosan/fullerene nanogels for efficient tumor therapy," Carbohydrate Polymers, vol. 101, pp. 692-698, 2014.

[119] S. Manchun, K. Cheewatanakornkool, C. R. Dass, and P. Sriamornsak, "Novel pH-responsive dextrin nanogels for doxorubicin delivery to cancer cells with reduced cytotoxicity to cardiomyocytes and stem cells," Carbohydrate Polymers, vol. 114, pp. 78-86, 2014.

[120] T. R. Arunraj, N. Sanoj Rejinold, N. Ashwin Kumar, and R. Jayakumar, "Bio-responsive chitin-poly (L-lactic acid) composite nanogels for liver cancer," Colloids and Surfaces B: Biointerfaces, vol. 113, pp. 394-402, 2014.

[121] M. Sabitha, N. Sanoj Rejinold, A. Nair, V. K. Lakshmanan, S. V. Nair, and R. Jayakumar, "Development and evaluation of 5-fluorouracil loaded chitin nanogels for treatment of skin cancer," Carbohydrate Polymers, vol. 91, no. 1, pp. 48-57, 2013.

[122] N. V. Nukolova, H. S. Oberoi, S. M. Cohen, A. V. Kabanov, and T. K. Bronich, "Folate-decorated nanogels for targeted therapy of ovarian cancer," Biomaterials, vol. 32, no. 23, pp. 5417-5426, 2011.

[123] J. Peng, T. Qi, J. Liao et al., "Controlled release of cisplatin from $\mathrm{pH}$-thermal dual responsive nanogels," Biomaterials, vol. 34, no. 34, pp. 8726-8740, 2013.

[124] K. Aoki, T. Sato, N. Alles et al., "Nanogel-crosslinked nanoparticles increase the inhibitory effects of W9 synthetic peptide on bone loss in a murine bone resorption model," International Journal of Nanomedicine, vol. 10, no. 1, pp. 3459-3473, 2015.
[125] X. Ma, L. Zhang, D. Fan et al., "Physicochemical properties and biological behavior of injectable crosslinked hydrogels composed of pullulan and recombinant human-like collagen," Journal of Materials Science, vol. 52, no. 7, pp. 37713785, 2017.

[126] M. Dimde, F. Neumann, F. Reisbeck et al., "Defined pHsensitive nanogels as gene delivery platform for siRNA mediated in vitro gene silencing," Biomaterials Science, vol. 5, no. 11, pp. 2328-2336, 2017.

[127] S. M. Mesbah Namini, A. Mohsenifar, R. Karami, T. Rahmani-Cherati, T. R. Shojaei, and M. Tabatabaei, "Kinetic properties of aryldialkylphosphatase immobilised on chitosan myristic acid nanogel," Chemical Papers, vol. 69 , no. 10, 2015.

[128] M. Witting, M. Molina, K. Obst et al., “Thermosensitive dendritic polyglycerol-based nanogels for cutaneous delivery of biomacromolecules," Nanomedicine: Nanotechnology, Biology and Medicine, vol. 11, no. 5, pp. 1179-1187, 2015.

[129] C. Dispenza, G. Adamo, M. A. Sabatino et al., "Oligonucleotides-decorated-poly (N-vinyl pyrrolidone) nanogels for gene delivery," Journal of Applied Polymer Science, vol. 131, no. 2, 2014.

[130] N. Bhuchar, R. Sunasee, K. Ishihara, T. Thundat, and R. Narain, "Degradable thermoresponsive nanogels for protein encapsulation and controlled release," Bioconjugate Chemistry, vol. 23, no. 1, pp. 75-83, 2011.

[131] H. Takahashi, S. I. Sawada, and K. Akiyoshi, "Amphiphilic polysaccharide nanoballs: a new building block for nanogel biomedical engineering and artificial chaperones," ACS Nano, vol. 5, no. 1, pp. 337-345, 2010.

[132] Y. Sasaki and K. Akiyoshi, "Nanogel engineering for new nanobiomaterials: from chaperoning engineering to biomedical applications," The Chemical Record, vol. 10, no. 6, pp. 366-376, 2010.

[133] A. S. Fouda, H. Megahed, Z. M. Mohamed, and M. Shaker, "Protection of corrosion of carbon steel with core-shell inorganic magnetic nanogels in formation water," International Journal of Electrochemical Science, vol. 11, pp. 8950-8963, 2016.

[134] P. L. Foley, B. D. Ulery, H. M. Kan et al., "A chitosan thermogel for delivery of ropivacaine in regional musculoskeletal anesthesia," Biomaterials, vol. 34, no. 10, pp. 2539-2546, 2013.

[135] T. Hoare, S. Young, M. W. Lawlor, and D. S. Kohane, "Thermoresponsive nanogels for prolonged duration local anesthesia," Acta Biomaterialia, vol. 8, no. 10, pp. 35963605, 2012.

[136] R. Grillo, N. F. S. de Melo, D. R. de Araújo, E. de Paula, A. H. Rosa, and L. F. Fraceto, "Polymeric alginate nanoparticles containing the local anesthetic bupivacaine," Journal of Drug Targeting, vol. 18, no. 9, pp. 688-699, 2010.

[137] Q. Q. Yin, L. Wu, M. L. Gou, Z. Y. Qian, W. S. Zhang, and J. Liu, "Long-lasting infiltration anaesthesia by lidocaineloaded biodegradable nanoparticles in hydrogel in rats," Acta Anaesthesiologica Scandinavica, vol. 53, no. 9, pp. 1207-1213, 2009.

[138] J. P. K. Tan, C. H. Goh, and K. C. Tam, "Comparative drug release studies of two cationic drugs from $\mathrm{pH}$-responsive nanogels," European Journal of Pharmaceutical Sciences, vol. 32, no. 4-5, pp. 340-348, 2007.

[139] H.-J. Kim, K. Zhang, L. Moore, and D. Ho, "Diamond nanogel-embedded contact lenses mediate lysozyme- 
dependent therapeutic release," ACS Nano, vol. 8, no. 3, pp. 2998-3005, 2014.

[140] H. A. Abd El-Rehim, A. E. Swilem, A. Klingner, E.-S. A. Hegazy, and A. A. Hamed, "Developing the potential ophthalmic applications of pilocarpine entrapped into polyvinylpyrrolidone-poly(acrylic acid) nanogel dispersions prepared by $\gamma$ radiation," Biomacromolecules, vol. 14, no. 3, pp. 688698, 2013.

[141] H. Gupta, M. Aqil, R. K. Khar, A. Ali, A. Bhatnagar, and G. Mittal, "Nanoparticles laden in situ gel of levofloxacin for enhanced ocular retention," Drug Delivery, vol. 20, no. 7, pp. 306-309, 2013.

[142] S. M. Mohammad and P. D. Turney, Nrc Emotion Lexicon, National Research Council, Canada, 2013.

[143] M. D. Moya-Ortega, C. Alvarez-Lorenzo, A. Concheiro, and T. Loftsson, "Cyclodextrin-based nanogels for pharmaceutical and biomedical applications," International Journal of Pharmaceutics, vol. 428, no. 1-2, pp. 152-163, 2012.

[144] R. C. Nagarwal, P. Nath Singh, S. Kant, P. Maiti, and J. K. Pandit, "Chitosan nanoparticles of 5-fluorouracil for ophthalmic delivery: characterization, in-vitro and in-vivo study," Chemical and Pharmaceutical Bulletin, vol. 59, no. 2, pp. 272-278, 2011. 


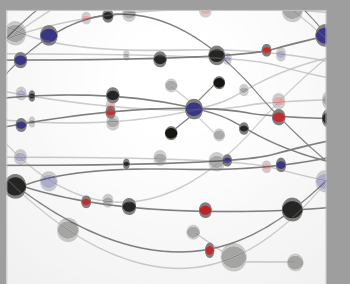

The Scientific World Journal
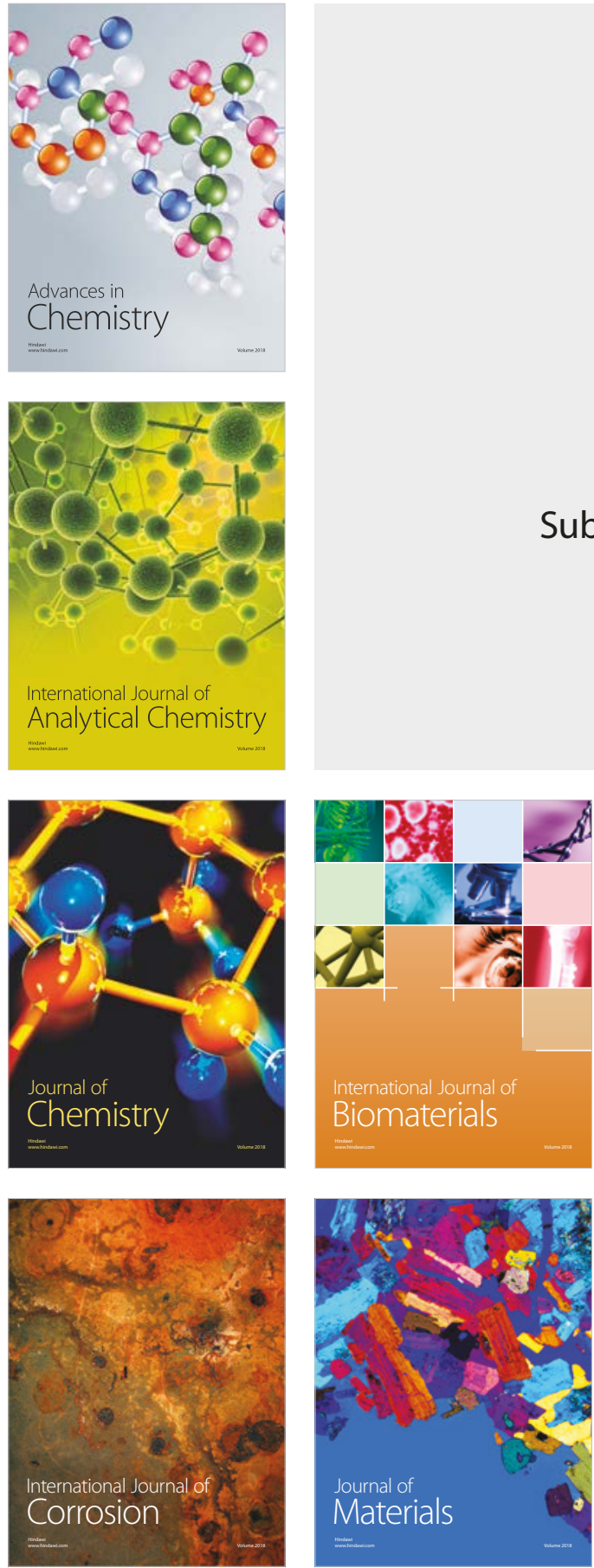

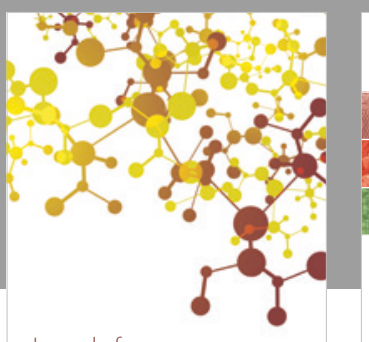

Journal of

Applied Chemistry
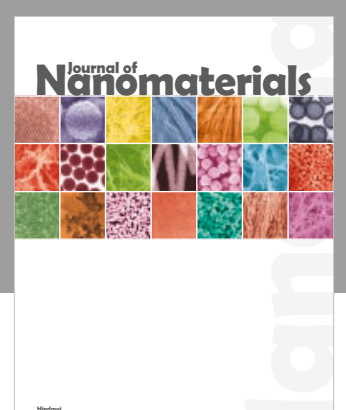

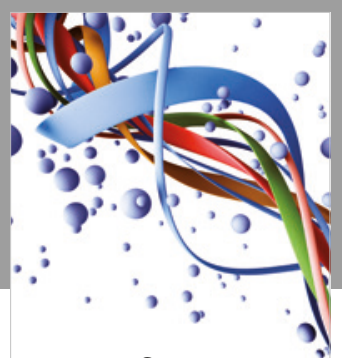

Scientifica

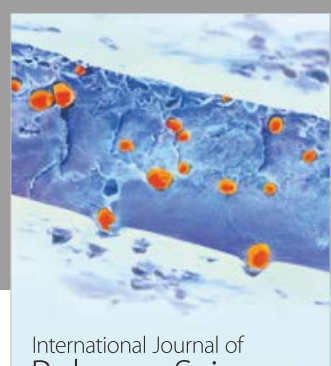

Polymer Science

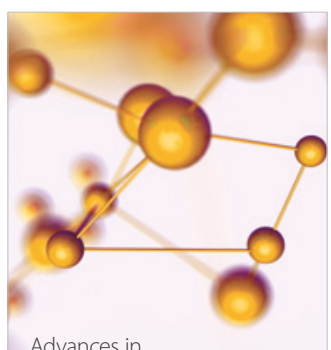

Physical Chemistry
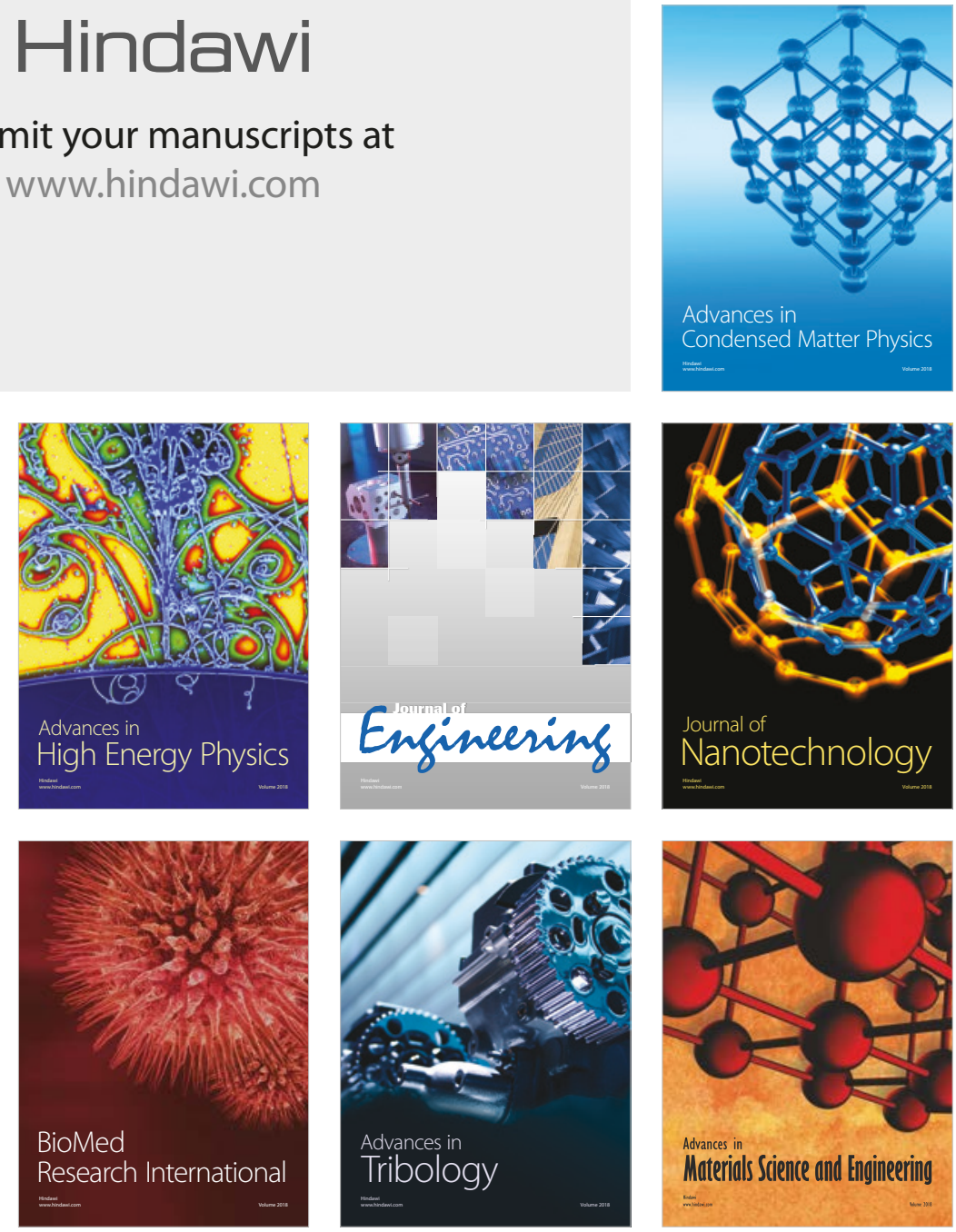